\title{
Tungsten(VI) Phenylimido Alkylidene Complexes Containing a Monoanionic O,N-Chelating Ligand and Their Isolated Precursor Complexes: X-ray Structures of $\mathrm{W}\left(\mathrm{CH}_{2} \mathrm{SiMe}_{3}\right)_{3}(=\mathrm{NPh})[\mathrm{OCPh}$ (2-py)] and $\mathrm{W}\left(=\mathrm{CHSiMe}_{3}\right)\left(\mathrm{CH}_{2} \mathrm{SiMe}_{3}\right)(=\mathrm{NPh})\left[\mathrm{OCPh}_{2}(2-\mathrm{py})\right]$
}

\author{
Paul A. van der Schaaf, ${ }^{\dagger}$ Robertus A. T. M. Abbenhuis, ${ }^{\dagger}$ \\ Walter P. A. van der Noort, ${ }^{\dagger}$ Robin de Graaf, ${ }^{\dagger}$ David M. Grove, ${ }^{\dagger}$ \\ Wilberth J. J. Smeets, ${ }^{\ddagger}$ Anthony L. Spek, ${ }^{\ddagger}$ and Gerard van Koten ${ }^{*}, \uparrow$ \\ Debye Institute, Department of Metal-Mediated Synthesis, and Bijvoet Center for \\ Biomolecular Research, Laboratory of Crystal and Structural Chemistry, Utrecht University, \\ Padualaan 8, 3584 CH Utrecht, The Netherlands
}

Received August 4, $1993^{\circ}$

\begin{abstract}
The lithium salts of selected phenoxides, with one or two potentially chelating $0 \cdot \mathrm{CH}_{2} \mathrm{NMe}_{2}$ substituents, 8-quinolinolate (8-quin), ortho-chelating arenethiolate ligands, and $\alpha$-substituted 2-pyridylmethoxides, were reacted with $\mathrm{W}\left(\mathrm{CH}_{2} \mathrm{SiMe}_{3}\right)_{3} \mathrm{Cl}(=\mathrm{NPh})$ (1) and $\mathrm{W}\left(\mathrm{CH}_{2} \mathrm{SiMe}_{3}\right)_{2} \mathrm{Cl}$ $(=\mathrm{NPh})\left(\mathrm{OCMe}_{3}\right)(2)$, respectively. It appears that steric properties of the monoanionic $\mathrm{O}, \mathrm{N}$ and S,N-chelating ligands are very important for inducing an intramolecular $\mathrm{H}_{\alpha}$-abstraction reaction; i.e., the phenoxide $\mathrm{OC}_{6} \mathrm{H}_{4} \mathrm{CH}_{2} \mathrm{NMe}_{2}-2$ (a) gave rise to the formation of alkylidene precursor $\mathrm{W}\left(\mathrm{CH}_{2} \mathrm{SiMe}_{3}\right)_{3}(=\mathrm{NPh})\left(\mathrm{OC}_{6} \mathrm{H}_{4} \mathrm{CH}_{2} \mathrm{NMe}_{2}-2\right)(3)$, in which the alkyl groups are still intact, whereas the "pincer phenolate" $\mathrm{OC}_{6} \mathrm{H}_{2}\left(\mathrm{CH}_{2} \mathrm{NMe}_{2}\right)_{2}-2,6-\mathrm{Me}-4$ (b), with two o- $\mathrm{CH}_{2} \mathrm{NMe}_{2}$ substituents, directly led to the formation of alkylidene complex $\mathrm{W}\left(=\mathrm{CHSiMe}_{3}\right)\left(\mathrm{CH}_{2}\right.$ $\left.\mathrm{SiMe}_{3}\right)(=\mathrm{NPh})\left(\mathrm{OC}_{6} \mathrm{H}_{2}\left(\mathrm{CH}_{2} \mathrm{NMe}_{2}\right)_{2}-2,6-\mathrm{Me}-4\right)\left(4^{\prime}\right)$. The reaction of 1 with $\mathrm{Na}$-8-quin instantaneously gave $\mathrm{W}\left(=\mathrm{CHSiMe}_{3}\right)\left(\mathrm{CH}_{2} \mathrm{SiMe}_{3}\right)(=\mathrm{NPh})\left(8\right.$-quin) $\left(5^{\prime}\right)$. Also, electronic properties play an important role in the formation of alkylidene complexes; i.e., the complexes derived from 2 , containing a $\pi$-electron-donating tert-butoxide group, are thermally more stable toward intramolecular $\mathrm{H}_{\alpha}$ abstraction than those derived from 1. With the $\alpha$-substituted 2-pyridylmethoxide ligands $\mathrm{OR}^{1} \mathrm{R}^{2}$ (2-py), in which the $\mathrm{R}$ substituents can be varied easily, we were able to prepare both the alkylidene precursor and the subsequent product of an intramolecular $\mathrm{H}_{\alpha}$-abstraction reaction, the tungsten(VI) alkylidene complex. The solid-state structure (Xray) of the trialkyltungsten(VI) precursor W( $\left.\mathrm{CH}_{2} \mathrm{SiMe}_{3}\right)_{3}(=\mathrm{NPh})[\mathrm{OCPh}$ (2-py)] (9) as well as the resulting alkylidene complex W( $\left.=\mathrm{CHSiMe}_{3}\right)\left(\mathrm{CH}_{2} \mathrm{SiMe}_{3}\right)(=\mathrm{NPh})\left[\mathrm{OCPh}_{2}(2-\mathrm{py})\right]\left(9^{\prime}\right)$ have been determined. Crystals of 9 are monoclinic, space group $P 2_{1} / c$, with unit-cell dimensions $a=10.974(1) \AA, b=18.531(3) \AA$, and $c=20.307(2) \AA, \beta=106.47(1)^{\circ}, Z=4$, final $R=0.063$, and $R_{\mathrm{w}}=0.053$ for 2644 reflections with $I>2.5 \sigma(I)$ and 415 parameters. Crystals of $9^{\prime}$ are triclinic, space group $P \overline{1}$, with unit-cell dimensions $a=9.4359(5) \AA, b=10.8887(7) \AA$, and $c=$ $16.611(1) \AA, \alpha=81.60(1)^{\circ}, \beta=88.37(1)^{\circ}, \gamma=79.19(1)^{\circ}, Z=2$, final $R=0.042$, and $R_{\mathrm{w}}=0.026$ for 5879 reflections with $I>2.5 \sigma(I)$ and 348 parameters. The two molecular structures clearly show the advantage of a $\mathrm{d}^{0}$ metal center in forming an alkylidene unit out of two alkyl groups. The chemical shift of $\mathrm{H}^{6}$, the hydrogen atom bonded at the ortho position with respect to the pyridyl nitrogen, as a probe shows that the pyridyl group in alkylidene complexes $9^{\prime}$ and $\mathrm{W}(=\mathrm{CHSiMe})\left(\mathrm{CH}_{2} \mathrm{SiMe}_{3}\right)(=\mathrm{NPh})\left[\mathrm{OCH}\left(\mathrm{CMe}_{3}\right)(2-\mathrm{py})\right]\left(10^{\prime}\right)$ can coordinate intramolecularly in the syn rotamer, whereas in the anti rotamer this will lead to considerable steric hindrance of the $\mathrm{SiMe}_{3}$ group of the alkylidene function with the vicinal substituents in the chelating ring. The reactivity of the present tungsten(VI) alkylidene complexes $5^{\prime}, 9^{\prime}$, and $10^{\prime}$ toward linear olefins is very low. However, aldehydes react with these complexes in Wittig-type reactions to yield predominantly the corresponding trans-olefin. Norbornene can be polymerized using these alkylidene complexes as a catalyst in a ring-opening metathesis reaction at $70^{\circ} \mathrm{C}$ to give polymeric cyclopentenes with $\geq 90 \%$ cis vinylene bonds.
\end{abstract}

\section{Introduction}

Since the first isolated and well-defined alkylidene complex was reported by Schrock in $1974,{ }^{1}$ a large number

* To whom correspondence should be addressed.

Debye Institute, Department of Metal-Mediated Synthesis.

: Bijvoet Center for Biomolecular Research, Laboratory of Crystal and Structural Chemistry.

- Abstract published in Advance ACS Abstracts, March 15, 1994

(1) Schrock, R. R. J. Am. Chem. Soc. 1974, 96, 6796. of papers have appeared in which the reactivity of these complexes is described. ${ }^{2,3}$ Extensive research has been carried out to synthesize well-characterized high-valent alkylidene complexes with controllable reactivities in olefin metathesis reactions. Up to now, two major types of welldefined alkylidene complexes have been available, i.e. four-

(2) Ivin, K. J. Olefin Metathesis; Academic Press, New York, 1983. (3) Dragutan, V.; Balaban, A. T.; Dimonie, M. Olefin Metathesis and Ring-Opening Polymerization of Cyclo-Olefins, 2nd ed.; WileyInterscience: New York, 1985. 


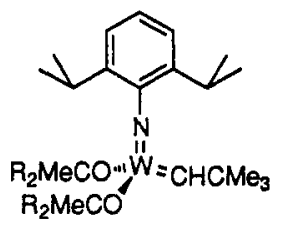

type A

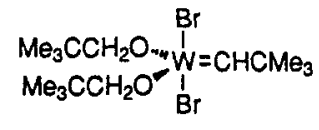

type B
Figure 1. Two examples of well-defined tungsten(VI) alkylidene complexes.

coordinate species (type A) such as W( $=\mathrm{CHCMe}_{3}$ )(=NAr) $\left(\mathrm{OCMeR}_{2}\right)_{2}\left(\mathrm{NAr}=\mathrm{NC}_{6} \mathrm{H}_{3} i-\mathrm{Pr}_{2}-2,6 ; \mathrm{R}=\mathrm{Me}\right.$ and $/$ or $\mathrm{CF}_{3}$ ) (see Figure 1) by Schrock and co-workers ${ }^{4}$ and five-coordinate species (type $\mathrm{B})$, of which $\mathrm{W}=\mathrm{CH}$ $\left.\mathrm{CMe}_{3}\right)\left(\mathrm{OCH}_{2} \mathrm{CMe}_{3}\right)_{2} \mathrm{Br}_{2}$ is a typical example (see Figure 1), by Osborn and co-workers. ${ }^{5}$

The type $\mathbf{A}$ complexes are all four-coordinate and have a pseudotetrahedral geometry. Type B complexes are dimeric in the solid state but are completely dissociated in solution, where they exist as five-coordinate monomeric species. The reactivity of these complexes strongly depends on the electron density at the metal center, and this can be tuned by changing the ligands. ${ }^{6}$ For example, a type $\mathbf{A}$ complex is much more reactive toward cis-2pentene with $\mathrm{OCMe}\left(\mathrm{CF}_{3}\right)_{2}$ ligands than with $\mathrm{OCMe}_{3}$ ligands. ${ }^{4 d}$ The type $\mathrm{B}$ complex $\mathrm{W}\left(=\mathrm{CHCMe}_{3}\right)\left(\mathrm{OCH}_{2}-\right.$ $\left.\mathrm{CMe}_{3}\right)_{2} \mathrm{Br}_{2}$, which is nearly inactive toward cis-2-pentene, has its reactivity enormously increased by addition of 2 equiv of the Lewis acid $\mathrm{GaBr}_{3} .{ }^{7}$ This enhanced reactivity is caused by the formation of four-coordinate cationic carbene species, such as $\mathrm{W}\left(=\mathrm{CHCMe}_{3}\right)\left(\mathrm{OCH}_{2} \mathrm{CMe}_{3}\right)_{2}$ $\mathrm{Br}^{+} \mathrm{Ga}_{2} \mathrm{Br}_{7}-$. Also, the polymer formation in ring-opening metathesis polymerization (ROMP) reactions initiated by these complexes is strongly influenced by the type of ligands attached to the metal center. ${ }^{8}$

Recently we published the first results of a new approach in this field of catalytic active species, viz. the preparation of high-valent tungsten phenylimido alkylidene complexes in which a potentially bidentate, monoanionic ligand is present. Our first approach was the synthesis of an alkylidene complex in which an arylamine ligand containing an ortho-chelating tertiary amine substituent is bonded to the metal center (see Figure 2). ${ }^{9}$

This particular tungsten(VI) alkylidene complex, which, both in the solid state and in solution, if five-coordinate as a result of intramolecular W-N coordination, is inactive

(4) (a) Schaverien, C. J.; Dewan, J. C.; Schrock, R. R. J. Am. Chem. Soc. 1986, 108, 2771. (b) Schrock, R. R.; Feldman, J.; Cannizzo, L. F.; Grubbs, R. H. Macromolecules 1987, 20, 1172. (c) Schrock, R. R.; Krouse S. A. Knoll, K.; Feldman, J.; Murdzek, J. S.; Yang, D. C. J. Mol. Catal. 1988, 46, 243. (d) Schrock, R. R.; DePue, R. T.; Feldman, J.; Schaverien, C. J.; Dewan, J. C.; Liu, A. H. J. Am. Chem. Soc. 1988, $110,1423$.

(5) (a) Kress, J.; Osborn, J. A.; Amir-Ebrahimi, V.; Ivin, K. J.; Rooney J. J. J. Chem. Soc., Chem. Commun. 1988, 1164. (b) Ivin, K. J.; Kress, J.; Osborn, J. A. J. Mol. Catal. 1988, 46, 351. (c) Greene, R. M. E.; Ivin, K. J.; Rooney, J. J.; Kress, J.; Osborn, J. A. Makromol. Chem. 1988, 189, 2797. (d) Greene, R. M. E.; Ivin, K. J.; Kress, J.; Osborn, J. A.; Rooney, J. J. Br. Polym. J. 1989, 21, 237. (e) Kress, J.; Osborn, J. A.; Ivin, K. J J. Chem. Soc., Chem. Commun. 1989, 1234.

(6) Cundari, T. R.; Gordon, M. S. J. Am. Chem. Soc. 1992, 114, 539.

(7) Kress, J.; Aguero, A.; Osborn, J. A. J. Mol. Catal. 1986, 36, 1.

(8) (a) Schrock, R. R.; Krouse, S. A.; Knoll, K.; Feldman, J.; Murdzek, J. S.; Yang, D. C. J. Mol. Catal. 1988, 46, 243. (b) Bazan, G. C.; Khosravi, E.; Schrock, R. R.; Feast, W. J.; Gibson, V. C.; O'Regan, M. B.; Thomas, J. K.; Davis, W. M. J. Am. Chem. Soc. 1990, 112, 8378. (c) Feast, W. J. Gibson, V. C.; Marshall, E. L. J. Chem. Soc., Chem. Commun. 1992, 1157. (9) (a) van der Schaaf, P. A.; Smeets, W. J. J.; Spek, A. L.; van Koten G. J. Chem. Soc., Chem. Commun. 1992, 717. (b) van der Schaaf, P. A. Grove, D. M.; Smeets, W. J. J.; Spek, A. L.; van Koten, G. Organometallics $1993,12,3955$.

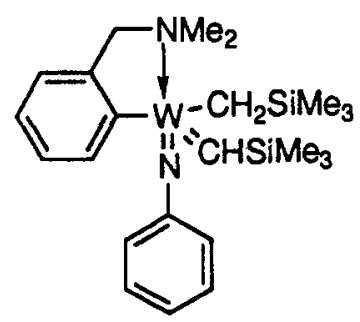

Figure 2. Five-coordinate tungsten(VI) alkylidene complex containing a bidentate $\mathrm{C}, \mathrm{N}$-bonded arylamine ligand.

toward linear olefins. However, it does react with strained cyclic olefins in a fast ring-opening metathesis polymerization reaction.

As mentioned above, the reactivity of the alkylidene function strongly depends on the electronic properties of the metal center. In order to tune the reactivity of this type of five-coordinate species, $\pi$-donating ligands can be introduced. ${ }^{10}$ This, combined with our approach of intramolecular coordination, led us to the idea of using phenoxide or alkoxide ligands which are capable of forming intramolecular dative bonds. In a preceding study we first established the accessibility of tungsten(VI) phenylimido chloride complexes containing this type of ligand, and we found that phenoxide ligands with one or two $0-\mathrm{CH}_{2} \mathrm{NMe}_{2}$ substituents (a and b, respectively), 8-quinolinolate (c), and $\alpha$-substituted 2-pyridylmethoxide, $\operatorname{OCR}^{1} \mathrm{R}^{2}(2-\mathrm{py})(\mathrm{g}-$ m) (see Figure 3) are suitable candidates. ${ }^{11 a}$ Three arenethiolate ligands (d-f) in which a potentially orthochelating amine group is present were tested as well.

The phenoxide and alkoxide ligands can easily be bonded to tungsten via a transmetalation reaction with the corresponding lithium salt. The complexes prepared in our preceding study (examples are given in Figure 4) ${ }^{11 a}$ are all six-coordinate species as a result of intramolecular W-N coordination and are all thermally very stable (e.g. $\left.T_{\text {dec }}(\mathbf{i}) \approx 350^{\circ} \mathrm{C}\right)$. It is this intramolecular W-N coordination which makes these complexes considerably more stable than the parent phenoxide complexes in which a diethyl ether molecule coordinates to the metal center ( $c f$. $T_{\mathrm{dec}}(\mathrm{iii}) \approx 150^{\circ} \mathrm{C}$ ).

In this paper the application of these potentially bidentate phenoxide and alkoxide ligands in the synthesis of high-valent tungsten alkylidene complexes is described.11b With these ligands bonded to bis- or tris[(trimethylsilyl)methyl]tungsten(VI) phenylimido chlorides, we have been able to isolate and characterize alkylidene complexes as well as their precursor complexes, depending on the ligand attached to the metal center. The structures of these complexes as well as the reactivity of the new alkylidene complexes toward olefins and aldehydes are presented.

\section{Results}

The alcohols used as ligands in this study were prepared via known, or modified, literature procedures (see Ex-

(10) (a) Schrock, R. R.; Rocklage, S. M.; Fellman, J. D.; Ruprecht, G. A.; Messerle, L. W. J. Am. Chem. Soc. 1981, 103, 1440. (b) Schrock, R. R.; DePue, R. T.; Feldman, J.; Yap, K. B.; Yang, D. C.; Davies, W. M.; Park, L.; DiMare, M.; Schofield, M.; Anhaus, J.; Walborsky, E.; Evitt, E.; Krüger, C.; Betz, P. Organometallics 1990, 9, 2262.

(11) (a) van der Schaaf, P. A.; Boersma, J.; Smeets, W. J. J.; Spek, A. L.; van Koten, G. Inorg. Chem. 1993, 32, 5108. (b) Recently, we briefly reported our initial results of this approach for the synthesis of alkylidene complexes: van der Schaaf, P. A.; Abbenhuis, R. A. T. M.; Grove, D. M.; Smeets, W. J. J.; Spek, A. L.; van Koten, G.J. Chem. Soc., Chem. Commun. 1993, 504 . 


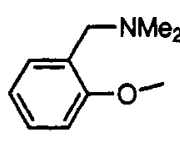

$\mathbf{a}$
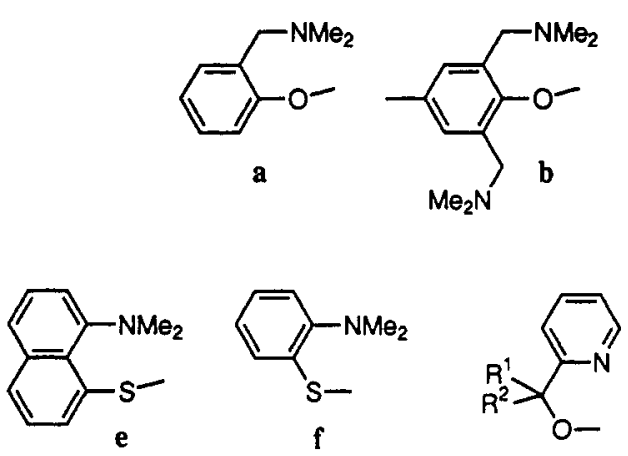

$$
\begin{aligned}
& \text { g } R^{1}=R^{2}=H \\
& \text { h } R^{1}=R^{2}=M e \\
& \text { i } R^{1}=M e ; R^{2}=P h \\
& \text { j } R^{1}=R^{2}=P h
\end{aligned}
$$

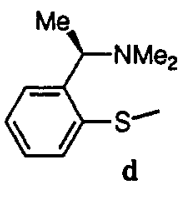

k $R^{1}=H ; R^{2}=t B u$
l $R^{1}=M e ; R^{2}=t B u$
m $R^{1}=R^{2}=F P r$

Figure 3. Selected $\mathrm{O}, \mathrm{N}$ - and $\mathrm{S}, \mathrm{N}$-chelating ligands.<smiles>Cc1cc(CN(C)C)c2c(c1)CN(C)C(Cl)(Cl)N(C)CO2</smiles>

i<smiles>CCOC(C)(Cl)N(Cl)N=Nc1ccccc1Oc1cc(C)cc(C)c1</smiles>

iii<smiles></smiles>

ii
Figure 4. Two examples of tungsten complexes with a bidentate aryloxy ligand (i and II) and one in which the sixth coordination site is occupied by a diethyl ether molecule (iii).

perimental Section). The monoanionic ligands were obtained from the $1: 1$ reaction of the alcohol with $n$-butyllithium and then transmetalated (as their lithium salts) to the trialkyl-or dialkyl-tert-butoxytungsten phenylimido chlorides $\mathrm{W}\left(\mathrm{CH}_{2} \mathrm{SiMe}_{3}\right)_{3} \mathrm{Cl}(=\mathrm{NPh})$ (1) and $\left.\mathrm{W}\left(\mathrm{CH}_{2} \mathrm{SiMe}_{3}\right)_{2} \mathrm{Cl}=\mathrm{NPh}\right)\left(\mathrm{OCMe}_{3}\right)(2)$, respectively. Characteristic NMR data for the free ligands (alcohols, or trimethylsilyl thioethers for the arenethiolates) are given in Tables 1 and 2.

Reactions of $\mathrm{W}\left(\mathrm{CH}_{2} \mathrm{SiMe}_{3}\right)_{3} \mathrm{Cl}(=\mathrm{NPh})$ (1) with the Lithium Salts of the $\mathbf{O}, \mathbf{N}$ - and $\mathbf{S}, \mathbf{N}$-Chelating Ligands. Reaction of $\mathrm{Li}\left(\mathrm{OC}_{6} \mathrm{H}_{4} \mathrm{CH}_{2} \mathrm{NMe}_{2}-2\right)$ with 1 in $\mathrm{Et}_{2} \mathrm{O}$ afforded $\mathrm{W}\left(\mathrm{CH}_{2} \mathrm{SiMe}_{3}\right)_{3}(=\mathrm{NPh})\left(\mathrm{OC}_{6} \mathrm{H}_{4} \mathrm{CH}_{2} \mathrm{NMe}_{2}-2\right)$ (3) in almost quantitative yield. The ${ }^{1} \mathrm{H}$ NMR spectrum of 3 shows the three (trimethylsilyl)methyl groups to be equivalent at room temperature as well as at low temperature $\left(-60^{\circ} \mathrm{C}\right)$. This implies that 3 has a trigonal-bipyramidal geometry with the monodentate $\mathrm{O}$-bonded phenoxide ligands and phenylimido group in apical positions, while the alkyl groups are bonded in the equatorial plane. Solutions of 3 are thermally very stable, and even after a 2 -h reflux in hexane no decomposition material could be detected. Reaction of 1 with the lithium "pincer phenolate" derived from $b$ (2 equiv is required, see Discussion) afforded $\mathrm{W}\left(=\mathrm{CHSiMe}_{3}\right)\left(\mathrm{CH}_{2} \mathrm{SiMe}_{3}\right)(=\mathrm{NPh})\left[\mathrm{OC}_{6} \mathrm{H}_{2}\left(\mathrm{CH}_{2} \mathrm{NMe}_{2}\right)_{2}-\right.$ $2,6-\mathrm{Me}-4]\left(4^{\prime}\right)^{12}$ in a rather unclean reaction. Attempts to purify $4^{\prime}$ by recrystallization or washing procedures were

(12) A prime (') in the number of a complex indicates that it is an alkylidene complex. unsuccessful because of its extremely good solubility. An NMR sample, taken from the crude reaction mixture, showed very complex resonance patterns, with two specific resonances, originating from alkylidene hydrogens, being present at $11.50\left({ }^{2} J_{\mathrm{WH}}\right.$ not observed) and $10.81 \mathrm{ppm}\left({ }^{2} J_{\mathrm{WH}}\right.$ $=12.0 \mathrm{~Hz}$ ) in a 6:4 ratio. According to data in the literature these two resonances can be ascribed to the anti- and synalkylidene rotamers, respectively. ${ }^{13}$ The other signals observed are in accordance with the presence of these two alkylidene rotamers, e.g. four $\mathrm{SiMe}_{3}$ signals and two different patterns for two bidentately $\mathrm{O}, \mathrm{N}$-bonded pincerphenolate ligands. Reaction of 1 with $\mathrm{Na}$-8-quinolinolate, derived from c, gave W(=CHSiMe $)\left(\mathrm{CH}_{2} \mathrm{SiMe}_{3}\right)(=\mathrm{NPh})-$ (8-quin) (5') as an almost pure, brown oil. Again a mixture of two alkylidene complexes was obtained, with an anti: syn rotamer ratio of 3:7, with resonances for $\mathrm{H}_{\alpha}$ at 11.70 $\left({ }^{2} J_{\mathrm{WH}}\right.$ not observed) and $10.65 \mathrm{ppm}\left({ }^{2} J_{\mathrm{WH}}=12.0 \mathrm{~Hz}\right)$, respectively.

The reactions of 1 with the lithium arenethiolates derived from $\mathbf{d}-\mathbf{f}$ afforded the triorganotungsten phenylimido arenethiolate complexes $\mathrm{W}\left(\mathrm{CH}_{2} \mathrm{SiMe}_{3}\right)_{3}(=\mathrm{NPh})$ [SC $\left.\mathrm{SH}_{4} \mathrm{CH}(\mathrm{Me}) \mathrm{NMe}_{2}-2\right]$ (6), W( $\left.\mathrm{CH}_{2} \mathrm{SiMe}_{3}\right)_{3}(=\mathrm{NPh})-$ $\left(\mathrm{SC}_{10} \mathrm{H}_{6} \mathrm{NMe}_{2}-8\right)(7)$, and $\mathrm{W}\left(\mathrm{CH}_{2} \mathrm{SiMe}_{3}\right)_{3}(=\mathrm{NPh})\left(\mathrm{SC}_{6} \mathrm{H}_{4}-\right.$ $\mathrm{NMe}_{2}-2$ ) (8) quantitatively as sticky oils (these products were pure by NMR spectroscopy, but no satisfactory elemental analyses could be obtained; this is most probably caused by the fact that they were isolated as sticky, airsensitive oils). According to ${ }^{1} \mathrm{H}$ and ${ }^{13} \mathrm{C}$ NMR data, the structure of these complexes is closely related to that of 3,i.e. a trigonal-bipyrimidal geometry with the alkyl groups bonded in the equatorial plane, and the phenylimido and thiolate sulfur bonded in the apical positions. Since 6 contains a stereogenic center, the fact that the $\mathrm{NMe}_{2}$ methyl groups are homotopic is unambiguous proof that the $\mathrm{NMe}_{2}$ groups do not coordinate to the metal center. Even at $-70^{\circ} \mathrm{C}$ the $\mathrm{NMe}_{2}$ methyl groups remain homotopic, indicating that also at this temperature no $\mathrm{W}-\mathrm{N}$ coordination occurs. Like 3, these complexes can be heated ( 24 $h$ at reflux in benzene) without any observable conversion to other products. In conclusion, these results show that the triorganotungsten complexes 3 and 6-8 in solution are five-coordinate species and that the potentially bidentate $\mathrm{O}, \mathrm{N}$ - and S,N-ligands are monodentate bonded (see Figure 5). Even in the presence of coordinating solvent molecules, such as $\mathrm{Et}_{2} \mathrm{O}$ or $\mathrm{THF}$, these complexes remain five-coordinate.

The reactions of lithium 2-pyridylmethoxides $\left(O C R^{1} R^{2}\right.$ (2-py)) derived from $\mathbf{g}-\mathbf{m}$ with 1 were mostly unclean and gave mixtures of products and decomposition material

(13) Schrock, R. R.; Crowe, W. E.; Bazan, G. C.; DiMare, M.; O'Regan, M. B.; Schofield, M. H. Organometallics 1991, 10, 1832. 
Table 1. ${ }^{1} \mathrm{H}$ and ${ }^{13} \mathrm{C}$ NMR Data" for the Phenols of a-c and (Trimethylsilyl)arenethiolates of d-f

\begin{tabular}{|c|c|c|c|c|c|c|}
\hline \multirow[b]{2}{*}{ ligand } & \multirow[b]{2}{*}{ compd } & \multicolumn{3}{|c|}{${ }^{13} \mathrm{C}$ NMR } & \multicolumn{2}{|c|}{${ }^{1} \mathrm{H}$ NMR } \\
\hline & & $\mathrm{C}_{\mathrm{ipso}}$ & $\mathrm{CH}_{2} \mathrm{~N}$ & $\mathrm{NMe}_{2}$ & $\mathrm{CH}_{2} \mathrm{~N}$ & $\mathrm{NMe}_{2}$ \\
\hline $\begin{array}{l}\text { a } \\
\text { b } \\
\text { c } \\
\text { d } \\
\text { e } \\
\text { f }\end{array}$ & $\begin{array}{l}\mathrm{HOC}_{6} \mathrm{H}_{4} \mathrm{CH}_{2} \mathrm{NMe}_{2}-2 \\
\mathrm{HOC}_{6} \mathrm{H}_{2}\left(\mathrm{CH}_{2} \mathrm{NMe}_{2}\right)_{2}-2,6-\mathrm{Me}-4 \\
\mathrm{HOC}_{7} \mathrm{H}_{6} \mathrm{~N}-8(=8-q u i n)^{b} \\
\left.\mathrm{Me}_{3} \mathrm{SiS}_{(2)}(\mathrm{R}) \mathrm{C}_{6} \mathrm{H}_{4} \mathrm{CH}(\mathrm{Me}) \mathrm{NMe}_{2}-2\right] \\
\mathrm{Me}_{2} \mathrm{SiSC}_{10} \mathrm{H}_{6} \mathrm{NMe}_{2}-8 \\
\mathrm{Me}_{3} \mathrm{SiSC}_{6} \mathrm{H}_{4} \mathrm{NMe}_{2}-2\end{array}$ & $\begin{array}{l}159.1 \\
154.7 \\
153.4 \\
149.3 \\
151.6 \\
156.0\end{array}$ & $\begin{array}{l}62.9 \\
60.3 \\
62.6^{c}\end{array}$ & $\begin{array}{l}44.0 \\
44.9 \\
43.8 \\
44.9 \\
43.9\end{array}$ & $\begin{array}{l}3.17 \\
3.48 \\
4.24^{d}\end{array}$ & $\begin{array}{l}1.76 \\
2.04 \\
\\
2.19 \\
2.64 \\
2.60\end{array}$ \\
\hline
\end{tabular}

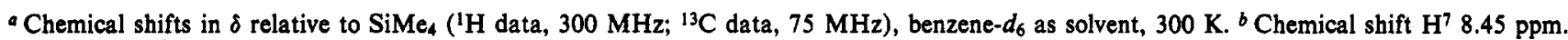
${ }^{c} \mathrm{CH}(\mathrm{Me}) 21.2 .{ }^{d} \mathrm{CH}(\mathrm{Me}) 1.30\left({ }^{3} J_{\mathrm{HH}}=6.6 \mathrm{~Hz}\right)$.

Table 2. ${ }^{1} \mathrm{H}$ and ${ }^{13} \mathrm{C}$ NMR Data* for the 2-Pyridylmethanol Derivatives

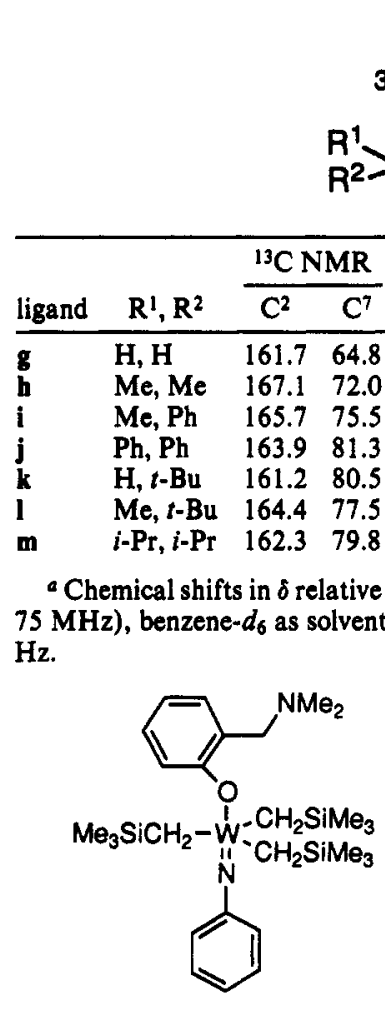

3

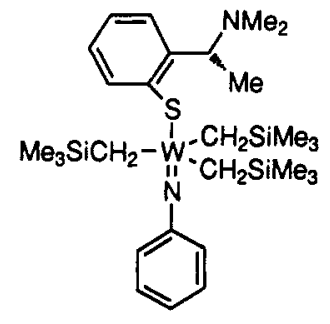

6

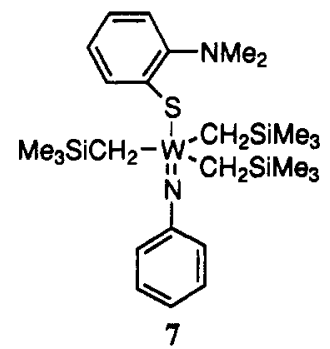

Figure 5. Proposed structures for the triorganotungsten phenylimido complexes 3, 6, and 7 .

that could not be separated by crystallization or washing procedures. However, with the ligands derived from $\mathbf{j}\left(R^{1}\right.$ $\left.=\mathrm{R}^{2}=\mathrm{Ph}\right)$ and $\mathbf{k}\left(\mathrm{R}^{1}=\mathrm{H} ; \mathrm{R}^{2}=t-\mathrm{Bu}\right)$ pure organometallic products were isolated.

Reaction of $\mathrm{Li}\left[\mathrm{OCPh}_{2}\right.$ (2-py)] with 1 in THF (reflux $>1$ h) afforded W( $\left.=\mathrm{CHSiMe}_{3}\right)\left(\mathrm{CH}_{2} \mathrm{SiMe}_{3}\right)(=\mathrm{NPh})\left[\mathrm{OCPh} \mathrm{C}_{2-}\right.$ (2-py)] $\left(9^{\prime}\right)$, which was isolated as a yellow crystalline product. A ${ }^{1} \mathrm{H}$ NMR spectrum in benzene- $d_{6}$ shows $9^{\prime}$ to be a mixture of two rotamers, in an anti:syn rotamer ratio of approximately 1:10, with alkylidene hydrogen resonances at $11.96\left({ }^{2} J_{\mathrm{WH}}\right.$ not observed) and $10.67 \mathrm{ppm}\left({ }^{2} J_{\mathrm{WH}}\right.$ $=11.4 \mathrm{~Hz}$ ), respectively. The chemical shift of $\mathrm{H}^{6}$ in

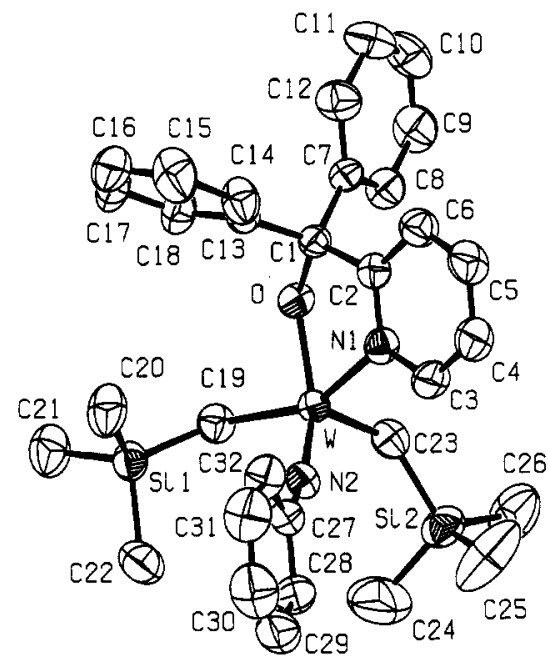

Figure 6. ORTEP plot (drawn at 50\% probability level) of the molecular structure of $\mathrm{W}(=\mathrm{CHSiMe})\left(\mathrm{CH}_{2} \mathrm{SiMe}_{3}\right)$ $(=\mathrm{NPh})\left[\mathrm{OCPh}{ }_{2}\right.$ (2-py)] (9') with part of the adopted numbering scheme ( $\mathrm{H}$ atoms are omitted for clarity).

complex $9_{8 y n}^{\prime}\left(\Delta \delta_{\mathrm{py}-\mathrm{H}^{8}}=0.30 \mathrm{ppm}\right)^{14}$ suggests that the pyridyl nitrogen atom intramolecularly coordinates to the tungsten center with the consequence that this complex is a five-coordinate alkylidene species, whereas for $\mathbf{9}^{\prime}$ anti $\Delta \delta_{\mathrm{py}-\mathrm{H}^{6}}=0.12 \mathrm{ppm}$.

To elucidate the geometry of the alkylidene complex $9^{\prime}$ and have further proof for the intramolecular pyridyl coordination, an X-ray structure determination was carried out. Suitable crystals were grown from a hexane solution at $-30^{\circ} \mathrm{C}$. The molecular structure of $\mathrm{W}\left(=\mathrm{CHSiMe}_{3}\right)-$ $\left(\mathrm{CH}_{2} \mathrm{SiMe}_{3}\right)(=\mathrm{NPh})\left[\mathrm{OCPh}_{2}\left(2\right.\right.$-py)] $\left(9^{\prime}\right)$ with the adopted numbering scheme is depicted in Figure 6. Final coordinates and selected bond distances and angles are given in Tables 3 and 4, respectively.

The molecular structure of $9^{\prime}$, as shown in Figure 6, is that of the syn rotamer (i.e. the major isomer in solution); viz., the trimethylsilyl group of the alkylidene function points toward the phenylimido group, and as already concluded from $\Delta \delta_{\mathrm{py}-\mathrm{H}^{6}}$ (vide supra), this rotamer is a fivecoordinate species as a result of intramolecular 2-pyridyl coordination. The geometry of $\boldsymbol{9}^{\prime}{ }_{s y n}$ can best be described as that of a distorted square pyramid (25.8\% distortion along the Berry pseudorotation axis toward a trigonal bipyramid) in which the alkylidene function occupies the apical position. The metal atom is slightly above the basal plane defined by the $\mathrm{N}(2)$-bonded phenylimido group, the $\mathrm{C}(19)$-bonded alkyl group, and the alkoxy oxygen $\mathrm{O}(1)$ with the 2-pyridyl nitrogen $N(1)$ of the chelating ligand. The bond lengths and angles within the alkylidene and phenylimido fragments are similar to those in $\mathrm{W}\left(\mathrm{C}_{6} \mathrm{H}_{4-}\right.$

(14) The superscript indices refer to the structure in the heading of Table 2. 
Table 3. Fractional Coordinates and Equivalent Isotropic Thermal Parameters for $\mathrm{W}\left(=\mathrm{CHSiMe}_{3}\right)\left(\mathrm{CH}_{2} \mathrm{SiMe}_{3}\right)(=\mathrm{NPh})\left[\mathrm{OCPh}_{2}\right.$ (2-py)] (9')

\begin{tabular}{lccll}
\hline atom & \multicolumn{1}{c}{$x$} & \multicolumn{1}{c}{$y$} & \multicolumn{1}{c}{$z$} & \multicolumn{1}{c}{$U_{\text {eq }}{ }^{a} \AA^{2}$} \\
\hline $\mathrm{W}$ & $0.24680(3)$ & $0.16139(2)$ & $0.78357(1)$ & $0.0336(1)$ \\
$\mathrm{Si}(1)$ & $0.01648(17)$ & $0.41474(14)$ & $0.67850(9)$ & $0.0462(5)$ \\
$\mathrm{Si}(2)$ & $0.4818(2)$ & $0.24581(18)$ & $0.91278(10)$ & $0.0635(7)$ \\
$\mathrm{O}$ & $0.1045(3)$ & $0.0524(3)$ & $0.80472(17)$ & $0.0387(12)$ \\
$\mathrm{N}(1)$ & $0.3579(5)$ & $-0.0318(4)$ & $0.7638(2)$ & $0.0411(16)$ \\
$\mathrm{N}(2)$ & $0.3578(4)$ & $0.2255(3)$ & $0.7083(2)$ & $0.0405(16)$ \\
$\mathrm{C}(1)$ & $0.1158(5)$ & $-0.0709(4)$ & $0.7846(3)$ & $0.0355(17)$ \\
$\mathrm{C}(2)$ & $0.2748(6)$ & $-0.1205(5)$ & $0.7719(3)$ & $0.0374(17)$ \\
$\mathrm{C}(3)$ & $0.5002(6)$ & $-0.0629(5)$ & $0.7501(3)$ & $0.050(2)$ \\
$\mathrm{C}(4)$ & $0.5648(6)$ & $-0.1850(6)$ & $0.7431(3)$ & $0.060(2)$ \\
$\mathrm{C}(5)$ & $0.4817(7)$ & $-0.2773(6)$ & $0.7529(3)$ & $0.059(2)$ \\
$\mathrm{C}(6)$ & $0.3361(6)$ & $-0.2462(5)$ & $0.7680(3)$ & $0.051(2)$ \\
$\mathrm{C}(7)$ & $0.0573(5)$ & $-0.1545(5)$ & $0.8555(3)$ & $0.0382(17)$ \\
$\mathrm{C}(8)$ & $0.0700(6)$ & $-0.1316(5)$ & $0.9347(3)$ & $0.050(2)$ \\
$\mathrm{C}(9)$ & $0.0193(7)$ & $-0.2081(6)$ & $0.9990(3)$ & $0.064(3)$ \\
$\mathrm{C}(10)$ & $-0.0409(7)$ & $-0.3085(6)$ & $0.9869(3)$ & $0.072(3)$ \\
$\mathrm{C}(11)$ & $-0.0534(7)$ & $-0.3332(6)$ & $0.9093(4)$ & $0.072(3)$ \\
$\mathrm{C}(12)$ & $-0.0053(6)$ & $-0.2554(5)$ & $0.8438(3)$ & $0.057(2)$ \\
$\mathrm{C}(13)$ & $0.0269(6)$ & $-0.0620(5)$ & $0.7075(3)$ & $0.0366(17)$ \\
$\mathrm{C}(14)$ & $0.0708(7)$ & $-0.1279(5)$ & $0.6441(3)$ & $0.057(2)$ \\
$\mathrm{C}(15)$ & $-0.0192(8)$ & $-0.1210(6)$ & $0.5784(3)$ & $0.079(3)$ \\
$\mathrm{C}(16)$ & $-0.1527(8)$ & $-0.0440(7)$ & $0.5753(4)$ & $0.078(3)$ \\
$\mathrm{C}(17)$ & $-0.1952(6)$ & $0.0252(6)$ & $0.6369(3)$ & $0.065(3)$ \\
$\mathrm{C}(18)$ & $-0.1064(6)$ & $0.0163(5)$ & $0.7024(3)$ & $0.055(2)$ \\
$\mathrm{C}(19)$ & $0.0647(6)$ & $0.3161(5)$ & $0.7785(3)$ & $0.0470(19)$ \\
$\mathrm{C}(20)$ & $0.0099(6)$ & $0.3162(5)$ & $0.5972(3)$ & $0.070(3)$ \\
$\mathrm{C}(21)$ & $-0.1643(6)$ & $0.5169(5)$ & $0.6856(3)$ & $0.075(3)$ \\
$\mathrm{C}(22)$ & $0.1496(6)$ & $0.5190(5)$ & $0.6494(3)$ & $0.072(3)$ \\
$\mathrm{C}(23)$ & $0.3329(6)$ & $0.1737(5)$ & $0.8818(3)$ & $0.0471(19)$ \\
$\mathrm{C}(24)$ & $0.4368(10)$ & $0.4158(7)$ & $0.8837(5)$ & $0.154(5)$ \\
$\mathrm{C}(25)$ & $0.6500(7)$ & $0.1851(8)$ & $0.8609(4)$ & $0.134(5)$ \\
$\mathrm{C}(26)$ & $0.5082(7)$ & $0.2100(7)$ & $1.0235(3)$ & $0.100(3)$ \\
$\mathrm{C}(27)$ & $0.4287(6)$ & $0.2440(5)$ & $0.6350(3)$ & $0.0413(17)$ \\
$\mathrm{C}(28)$ & $0.5194(6)$ & $0.3313(5)$ & $0.6216(3)$ & $0.055(2)$ \\
$\mathrm{C}(29)$ & $0.5884(7)$ & $0.3506(6)$ & $0.5472(4)$ & $0.072(3)$ \\
$\mathrm{C}(30)$ & $0.5686(7)$ & $0.2814(7)$ & $0.4860(4)$ & $0.078(3)$ \\
$\mathrm{C}(31)$ & $0.4827(7)$ & $0.1941(6)$ & $0.4982(3)$ & $0.074(3)$ \\
$\mathrm{C}(32)$ & $0.4119(6)$ & $0.1739(5)$ & $0.5736(3)$ & $0.057(2)$ \\
& & &
\end{tabular}

a $U_{e q}$ is equal to one-third of the trace of the orthogonalized $\mathrm{U}$.

Table 4. Geometrical Data for $\mathrm{W}\left(=\mathrm{CHSiMe}_{3}\right)\left(\mathrm{CH}_{2} \mathrm{SiMe}_{3}\right)(=\mathrm{NPh})\left[\mathrm{OCPh}_{2}(2-\mathrm{py})\right]\left(9^{\prime}\right)$

\begin{tabular}{|c|c|c|c|}
\hline \multicolumn{4}{|c|}{ Bond Lengths $(\AA)$} \\
\hline W-C(23) & $1.876(5)$ & w-ó & $1.945(3)$ \\
\hline W-C $(19)$ & $2.163(6)$ & $\mathrm{W}-\mathrm{N}(1)$ & $2.233(4)$ \\
\hline W-N(2) & $1.758(4)$ & $C(1)-0$ & $1.415(5)$ \\
\hline$C(23)-S i(2)$ & $1.852(6)$ & $\mathrm{C}(19)-\mathrm{Si}(1)$ & $1.860(5)$ \\
\hline \multicolumn{4}{|c|}{ Bond Angles (deg) } \\
\hline $\mathrm{W}-\mathrm{C}(23)-\mathrm{Si}(2)$ & $136.4(3)$ & $0-W-N(1)$ & $73.39(15)$ \\
\hline $\mathrm{W}-\mathrm{C}(19)-\mathrm{Si}(1)$ & $118.2(3)$ & $\mathrm{O}-\mathrm{W}-\mathrm{N}(2)$ & $144.14(14)$ \\
\hline $\mathrm{W}-\mathrm{N}(2)-\mathrm{C}(27)$ & $159.3(3)$ & O-W-C(19) & $85.59(18)$ \\
\hline$N(1)-W-C(23)$ & $99.99(19)$ & $\mathrm{O}-\mathrm{W}-\mathrm{C}(23)$ & $109.55(19)$ \\
\hline $\mathrm{N}(1)-\mathrm{W}-\mathrm{C}(19)$ & $154.22(19)$ & $\mathrm{N}(2)-\mathrm{W}-\mathrm{C}(19)$ & $100.15(18)$ \\
\hline $\mathrm{N}(1)-\mathrm{W}-\mathrm{N}(2)$ & $89.01(15)$ & $N(2)-W-C(23)$ & $104.1(2)$ \\
\hline$C(19)-W-C(23)$ & $101.0(2)$ & & \\
\hline
\end{tabular}

$\left.\mathrm{CH}_{2} \mathrm{NMe}_{2}-2\right)\left(=\mathrm{CHSiMe}_{3}\right)\left(\mathrm{CH}_{2} \mathrm{SiMe}_{3}\right)(=\mathrm{NPh})^{9}$ (see Figure 2). The W-N(1) bond length of 2.233(4) $\AA$ is typical for $\mathrm{sp}^{2}$ nitrogen to tungsten coordination. ${ }^{15}$

In a ${ }^{1} \mathrm{H}$ NMR spectrum of crude $\mathbf{9}^{\prime}$, from a reaction mixture that had been heated at reflux for only a few minutes, some resonances of a second compound, 9 , could be seen. These resonances are consistent with 9 containing one alkoxide ligand and three equivalent alkyl groups; i.e., it has the composition $\mathrm{W}\left(\mathrm{CH}_{2} \mathrm{SiMe}_{3}\right)_{3}(=\mathrm{NPh})\left[\mathrm{OCPh}_{2-}\right.$ (2-py)] and can be considered as the precursor of the

(15) (a) Hanson, I. R.; Hughes, D. L. J. Chem. Soc., Dalton Trans. 1981, 390. (b) Chatt, J.; Fakley, M. E.; Richards, R. L.; Hanson, I. R.; Hughes, D. L. J. Organomet. Chem. 1979, 170, C6. (c) Day, R. O.; Batschelet, W. H.; Archer, R. D. Inorg. Chem. 1980, 19, 2113. (d) Bonds, W. D.; Archer, R. D.; Hamilton, W. C. Inorg. Chem. 1971, 10, 1764.

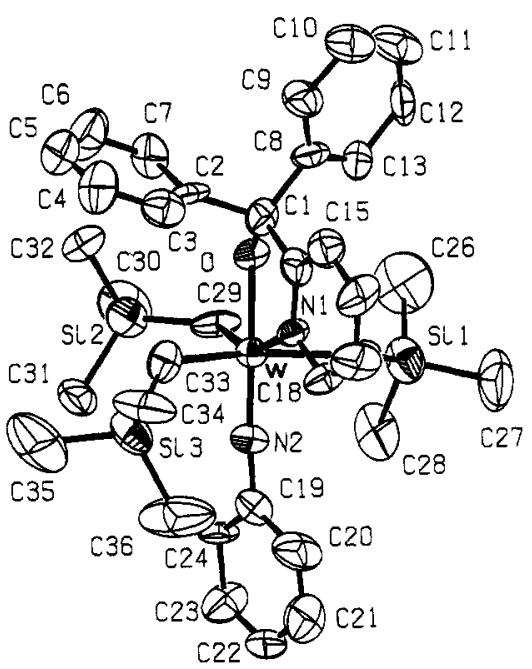

Figure 7. ORTEP plot (drawn at 50\% probability level) of the molecular structure of $\mathrm{W}\left(\mathrm{CH}_{2} \mathrm{SiMe}_{3}\right)_{3}(=\mathrm{NPh})\left[\mathrm{OCPh}_{2}\right.$ (2-py)] (9) with part of the adopted numbering scheme $(\mathrm{H}$ atoms are omitted for clarity).

tungsten alkylidene complex $9^{\prime}$. Several unsuccessful attempts have been made to synthesize 9 by employing different conditions such as using pyridine as solvent instead of THF and carrying out the reaction at lower temperatures. A second reaction route in which $\mathrm{WCl}_{3}(=\mathrm{NPh})\left[\mathrm{OCPh}_{2}(2 \text {-py) }]^{11 \mathrm{a}}\right.$ was reacted with 3 equiv of $\mathrm{LiCH}_{2} \mathrm{SiMe}_{3}$ (both reagents are soluble in $\mathrm{Et}_{2} \mathrm{O}$ at low temperatures) was unsuccessful as well. However, when $\mathrm{Li}\left[\mathrm{OCH}\left(\mathrm{CMe}_{3}\right)\right.$ (2-py)] was reacted with 1 at room temperature the trialkyltungsten alkoxide $\mathrm{W}\left(\mathrm{CH}_{2} \mathrm{SiMe}_{3}\right)_{3}$ $(=\mathrm{NPh})\left[\mathrm{OCH}\left(\mathrm{CMe}_{3}\right)(2\right.$-py)] (10) was obtained almost quantitatively. This complex can be isolated and stored for long periods at $-30^{\circ} \mathrm{C}$ without decomposition, but in solution at ambient temperatures a slow $\mathrm{H}_{\alpha}$-abstraction reaction occurs. When 10 is heated at reflux in hexane for at least $4 \mathrm{~h}$, the corresponding alkylidene complex $\mathrm{W}\left(=\mathrm{CHSiMe}_{3}\right)\left(\mathrm{CH}_{2} \mathrm{SiMe}_{3}\right)(=\mathrm{NPh})\left[\mathrm{OCH}\left(\mathrm{CMe}_{3}\right)(2-\right.$ py)] $\left(10^{\prime}\right)$ is obtained quantitatively. According to its ${ }^{1} \mathrm{H}$ NMR spectrum, $10^{\prime}$ is (like $9^{\prime}$ ) present as an anti and syn rotamer mixture now in a $4: 6$ ratio, with alkylidene hydrogen resonances at $11.63\left({ }^{2} J_{\mathrm{WH}}\right.$ not observed) and $10.75 \mathrm{ppm}\left({ }^{2} J_{\mathrm{WH}}=11.1 \mathrm{~Hz}\right)$, respectively. Two other alkylidene resonances (at 11.01 and $10.98 \mathrm{ppm}$ ) are also present with a total integral of $c a .5 \%$ with respect to the two major alkylidene signals.

At this stage we spent much time trying to obtain crystals of 10 that would be suitable for an X-ray diffraction study in order to compare the structural features of this alkylidene precursor with those of the tungsten(VI) alkylidene complex $9^{\prime}$. As all attempts failed because of the extremely good solubility of 10 , we turned our attention to incomplete reaction mixtures for the synthesis of $\mathbf{9}^{\prime}$ (vide supra). A deviating crystal was selected out of a batch of crystals obtained from a reaction mixture of $9^{\prime}$ which was heated for only several minutes. Figure 7 shows that this practical approach was successful. The molecular structure of $\mathrm{W}\left(\mathrm{CH}_{2} \mathrm{SiMe}_{3}\right)_{3}(=\mathrm{NPh})\left[\mathrm{OCPh}_{2}(2-\mathrm{py})\right](9)$, along with the adopted numbering scheme, is shown in Figure 7, while the final coordinates and selected bond distances and angles are given in Tables 5 and 6 , respectively.

The molecular structure of 9 can be described as a slightly distorted octahedron in which the $N(2)$-bonded phenylimido group and the $\mathrm{O}(1)$-bonded alkoxide occupy 
Table 5. Fractional Coordinates and Equivalent Isotropic Thermal Parameters for $\mathrm{W}\left(\mathrm{CH}_{2} \mathrm{SiMe}_{3}\right)_{3}(=\mathrm{NPh})\left[\mathrm{OCPh}_{2}(2-\mathrm{py})\right]$ (9)

\begin{tabular}{|c|c|c|c|c|}
\hline atom & $x$ & $y$ & $z$ & $U_{e q},{ }^{a} \AA^{2}$ \\
\hline W & $1.12776(8)$ & $0.32603(4)$ & $0.28073(4)$ & $0.0381(2)$ \\
\hline $\mathrm{Si}(1)$ & $0.9053(6)$ & $0.3074(4)$ & $0.1190(3)$ & $0.071(3)$ \\
\hline $\mathrm{Si}(2)$ & $1.0118(6)$ & $0.4730(3)$ & $0.3570(3)$ & $0.064(2)$ \\
\hline $\mathrm{Si}(3)$ & $1.3074(6)$ & $0.2432(4)$ & $0.4442(3)$ & $0.071(3)$ \\
\hline$O(1)$ & $1.2360(11)$ & $0.3987(6)$ & $0.2543(6)$ & $0.038(4)$ \\
\hline $\mathbf{N}(1)$ & $1.2981(13)$ & $0.2680(8)$ & $0.2606(7)$ & $0.037(5)$ \\
\hline$N(2)$ & $1.0256(13)$ & $0.2665(7)$ & $0.3045(7)$ & $0.039(5)$ \\
\hline$C(1)$ & $1.3576(18)$ & $0.3931(11)$ & $0.2472(10)$ & $0.050(5)$ \\
\hline$C(2)$ & $1.4551(19)$ & $0.4260(11)$ & $0.3145(11)$ & $0.051(5)$ \\
\hline$C(3)$ & $1.5556(18)$ & $0.3898(11)$ & $0.3572(10)$ & $0.064(6)$ \\
\hline$C(4)$ & $1.630(2)$ & $0.4240(14)$ & $0.4157(11)$ & $0.092(6)$ \\
\hline$C(5)$ & $1.607(2)$ & $0.4915(15)$ & $0.4311(12)$ & $0.103(6)$ \\
\hline$C(6)$ & $1.511(2)$ & $0.5279(13)$ & $0.3857(12)$ & $0.091(6)$ \\
\hline$C(7)$ & $1.4375(17)$ & $0.4948(11)$ & $0.3298(9)$ & $0.057(5)$ \\
\hline$C(8)$ & $1.3736(19)$ & $0.4288(9)$ & $0.1814(11)$ & $0.050(6)$ \\
\hline$C(9)$ & $1.493(2)$ & $0.4530(10)$ & $0.1820(11)$ & $0.066(6)$ \\
\hline$C(10)$ & $1.498(2)$ & $0.4843(11)$ & $0.1192(11)$ & $0.078(6)$ \\
\hline$C(11)$ & $1.397(2)$ & $0.4913(12)$ & $0.0649(12)$ & $0.092(6)$ \\
\hline$C(12)$ & $1.281(2)$ & $0.4655(10)$ & $0.0661(9)$ & $0.062(6)$ \\
\hline$C(13)$ & $1.2680(19)$ & $0.4326(11)$ & $0.1280(9)$ & $0.053(6)$ \\
\hline$C(14)$ & $1.3829(17)$ & $0.3102(10)$ & $0.2420(8)$ & $0.047(5)$ \\
\hline$C(15)$ & $1.4816(19)$ & $0.2809(11)$ & $0.2223(9)$ & $0.057(5)$ \\
\hline$C(16)$ & $1.494(2)$ & $0.2066(11)$ & $0.2164(10)$ & $0.066(6)$ \\
\hline$C(17)$ & $1.4057(19)$ & $0.1647(10)$ & $0.2339(10)$ & $0.069(6)$ \\
\hline$C(18)$ & $1.3097(19)$ & $0.1959(10)$ & $0.2547(9)$ & $0.057(6)$ \\
\hline$C(19)$ & $0.9335(19)$ & $0.2203(12)$ & $0.3160(10)$ & $0.044(5)$ \\
\hline$C(20)$ & $0.937(2)$ & $0.1472(13)$ & $0.2981(11)$ & $0.077(6)$ \\
\hline$C(21)$ & $0.850(2)$ & $0.0990(12)$ & $0.3075(11)$ & $0.081(6)$ \\
\hline$C(22)$ & $0.760(2)$ & $0.1227(11)$ & $0.3384(10)$ & $0.074(6)$ \\
\hline$C(23)$ & $0.7592(17)$ & $0.1908(11)$ & $0.3567(10)$ & $0.067(6)$ \\
\hline$C(24)$ & $0.8462(16)$ & $0.2409(10)$ & $0.3450(9)$ & $0.047(5)$ \\
\hline$C(25)$ & $1.0648(15)$ & $0.2834(9)$ & $0.1777(8)$ & $0.047(5)$ \\
\hline$C(26)$ & $0.896(2)$ & $0.3975(13)$ & $0.0863(12)$ & $0.147(7)$ \\
\hline$C(27)$ & $0.878(2)$ & $0.2442(13)$ & $0.0446(10)$ & $0.116(6)$ \\
\hline$C(28)$ & $0.7740(16)$ & $0.2888(12)$ & $0.1554(10)$ & $0.092(6)$ \\
\hline$C(29)$ & $1.0102(18)$ & $0.4168(9)$ & $0.2828(9)$ & $0.056(5)$ \\
\hline$C(30)$ & $0.873(2)$ & $0.5333(11)$ & $0.3347(11)$ & $0.104(6)$ \\
\hline$C(31)$ & $0.996(2)$ & $0.4178(10)$ & $0.4322(9)$ & $0.086(6)$ \\
\hline$C(32)$ & $1.1619(19)$ & $0.5286(11)$ & $0.3851(10)$ & $0.084(6)$ \\
\hline$C(33)$ & $1.2657(15)$ & $0.3172(10)$ & $0.3793(8)$ & $0.054(5)$ \\
\hline$C(34)$ & $1.472(4)$ & $0.209(2)$ & $0.445(2)$ & $0.097(7)$ \\
\hline$C(35)$ & $1.323(6)$ & $0.280(3)$ & $0.533(2)$ & $0.147(7)$ \\
\hline$C(36)$ & $1.203(5)$ & $0.161(3)$ & $0.425(3)$ & $0.161(8)$ \\
\hline
\end{tabular}

${ }^{a} \mathrm{U}(\mathrm{eq})$ is equal to one-third of the trace of the orthogonalized $U$.

Table 6. Geometrical Data for $\mathrm{W}\left(\mathrm{CH}_{2} \mathrm{SiMe}_{3}\right)_{3}(=\mathrm{NPh})\left[\mathrm{OCPh}_{2}(2-\mathrm{py})\right]$ (9)

\begin{tabular}{|c|c|c|c|}
\hline \multicolumn{4}{|c|}{ Bond Lengths $(\AA)$} \\
\hline$W-C(25)$ & $2.159(16)$ & w-o & $1.968(12)$ \\
\hline$W-C(29)$ & $2.127(18)$ & $\mathrm{W}-\mathrm{N}(1)$ & $2.292(15)$ \\
\hline $\mathrm{W}-\mathrm{C}(33)$ & $2.146(16)$ & W-N(2) & $1.736(14)$ \\
\hline$C(1)-0$ & $1.39(2)$ & $C(25)-S i(1)$ & $1.871(18)$ \\
\hline $\mathrm{C}(29)-\mathrm{Si}(2)$ & $1.828(18)$ & $\mathrm{C}(33)-\mathrm{Si}(3)$ & $1.867(19)$ \\
\hline \multicolumn{4}{|c|}{ Bond Angles (deg) } \\
\hline $\mathrm{W}-\mathrm{C}(25)-\mathrm{Si}(1)$ & $121.0(9)$ & $\mathrm{O}-\mathrm{W}-\mathrm{N}(1)$ & $71.7(5)$ \\
\hline W-C(29)-Si(2) & $127.1(10)$ & $\mathrm{O}-\mathrm{W}-\mathrm{N}(2)$ & $176.2(6)$ \\
\hline $\mathrm{W}-\mathrm{C}(33)-\mathrm{Si}(3)$ & $132.9(10)$ & $\mathbf{N}(1)-\mathbf{W}-\mathbf{N}(2)$ & $112.0(6)$ \\
\hline$N(1)-W-C(25)$ & $73.1(6)$ & $C(25)-W-C(29)$ & $106.2(7)$ \\
\hline$C(29)-W-C(33)$ & $108.2(7)$ & $\mathrm{C}(33)-\mathrm{W}-\mathrm{N}(1)$ & $74.6(6)$ \\
\hline $\mathrm{W}-\mathrm{N}(2)-\mathrm{C}(19)$ & $173.2(13)$ & & \\
\hline
\end{tabular}

mutually trans positions. The $\mathrm{C}(25)-, \mathrm{C}(29)-$, and $\mathrm{C}(33)-$ bonded (trimethylsilyl)methyl groups and the 2-pyridyl nitrogen $N(1)$ are bonded in the equatorial plane. The $\mathrm{W}-\mathrm{N}(1), \mathrm{W}-\mathrm{N}(2)$, and $\mathrm{W}-\mathrm{O}(1)$ bond lengths are very similar to those in the molecular structure of $9^{\prime}$. The $\mathrm{W}-\mathrm{C}(25,29$, and 33$)$ bond lengths are typical for alkyl groups bonded to tungsten(VI). The large angle made by one of the alkyl groups, i.e. W-C(33)-Si(3) $=132.9(10)^{\circ}$, is surprising. The angle around the imido nitrogen in 9 is significantly larger than this angle in $9^{\prime} ;$ i.e., W-N(2)$\mathrm{C}(19)=173.2(13)^{\circ}(9)$ and $\mathrm{W}-\mathrm{N}(2)-\mathrm{C}(27)=159.3(3)^{\circ}\left(9^{\prime}\right)$.
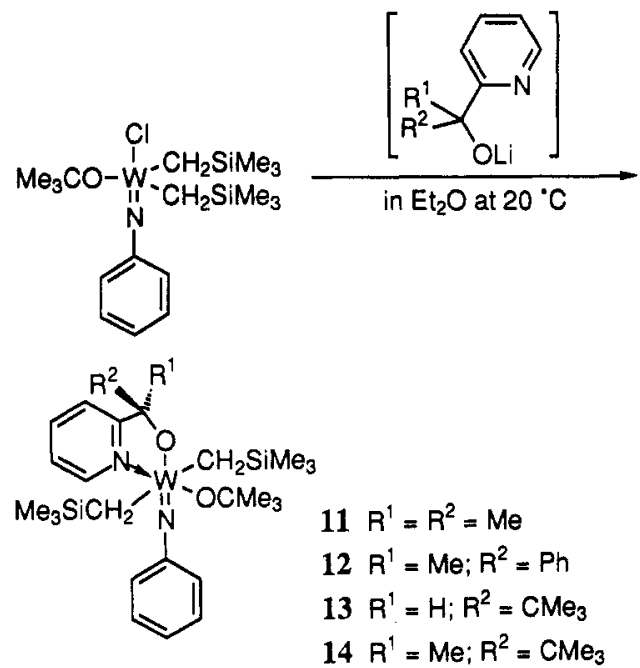

Figure 8. Product formation of and proposed structure for complexes 11-14.

Reactions of W( $\left.\mathrm{CH}_{2} \mathrm{SiMe}_{3}\right)_{2} \mathrm{Cl}(=\mathrm{NPh})\left(\mathrm{OCMe}_{3}\right)(2)$ with Li[OR $\left.{ }^{1} R^{2}(2-p y)\right]$. As a result of the large influence of the $R^{1}$ and $R^{2}$ substituents in the 2-pyridylmethoxide ligands $\left(O C R^{1} R^{2}(2-p y)\right)$ on the formation of alkylidene complexes in reactions with 1 , these ligands were also used in the reactions with the less electron deficient tungsten complex W $\left(\mathrm{CH}_{2} \mathrm{SiMe}_{3}\right)_{2} \mathrm{Cl}(=\mathrm{NPh})\left(\mathrm{OCMe}_{3}\right)(2)$. Howev$\mathrm{er}$, in the organotungsten(VI) complexes thus formed the properties of these substituents play a less important role. All reactions afforded only one type of product, i.e. $\mathrm{W}\left(\mathrm{CH}_{2}-\right.$ $\left.\mathrm{SiMe}_{3}\right)_{2}(=\mathrm{NPh})\left(\mathrm{OCMe}_{3}\right)\left[O C \mathrm{CR}^{1} \mathrm{R}^{2}(2-\mathrm{py})\right]\left(11-14: \mathrm{R}^{1}=\mathrm{R}^{2}\right.$ $=\mathrm{Me}, 11 ; \mathrm{R}^{1}=\mathrm{Me}, \mathrm{R}^{2}=\mathrm{Ph}, 12 ; \mathrm{R}^{1}=\mathrm{H}, \mathrm{R}^{2}=\mathrm{CMe}_{3}, 13$; $\left.\mathrm{R}^{1}=\mathrm{Me}, \mathrm{R}^{2}=\mathrm{CMe}_{3}, 14\right)$.

The values of $\Delta \delta_{\mathrm{py}-\mathrm{H}^{6}}$ for these complexes range from 0.49 to $0.87 \mathrm{ppm}$, suggesting that the pyridyl fragment intramolecularly coordinates to the metal center in all complexes. This is consistent with the resonance patterns observed for the $\mathrm{CH}_{2} \mathrm{Si}$ hydrogens, i.e. one $\mathrm{AB}$ pattern for 11 and two $\mathrm{AB}$ patterns for 12-14 (in which the $\mathrm{C}_{\alpha}$ atom of the methoxide ligand is a stereogenic center), and for the $\mathrm{CH}_{2} \mathrm{Si}$ carbon atoms, i.e. one signal for 11 and two signals for 12-14. These combined data indicate that these complexes are six-coordinate as a result of intramolecular pyridyl coordination, with the alkyl groups bonded in the equatorial plane trans with respect to each other. The proposed structure for 11-14 is depicted in Figure 8.

Compared to the above-mentioned trialkyltungsten complexes 9 and 10 , these complexes have greatly enhanced thermal stability. Complexes 11-14 are stable as solids (under an inert atmosphere), while solutions in benzene can be heated at reflux to afford only traces of alkylidene complexes. Accordingly, none of these complexes gave a pure alkylidene complex after $24 \mathrm{~h}$ at reflux. Even heating solid 12 for $7 \mathrm{~h}$ at $70^{\circ} \mathrm{C}$ in vacuo $(<0.1 \mathrm{mmHg})$ did not result in the formation of any new products. Also 11a, in which the (trimethylsilyl)methyl groups present in 11 have been replaced by neopentyl groups (which are known to be more susceptible to $\mathrm{H}_{\alpha}$-abstraction reactions), ${ }^{16}$ was found to be stable and not to give an alkylidene complex. When the tert-butoxide ligand was replaced by the less electron donating 3,5-dimethylphenoxide group, again a six-coordinate dialkyltungsten phenylimido complex, $\mathrm{W}\left(\mathrm{CH}_{2} \mathrm{SiMe}_{3}\right)_{2}(=\mathrm{NPh})\left(\mathrm{OC}_{6} \mathrm{H}_{3} \mathrm{Me}_{2}-3,5\right)\left[\mathrm{OCMe}_{2}(2-\mathrm{py})\right]$ (15)

(16) Schrock, R. R. Acc. Chem. Res. 1979, 12, 98. 
Table 7. Results of Norbornene Polymerization with Alkylidenes $\mathrm{W}\left(=\mathrm{CHSiMe}_{3}\right)\left(\mathrm{CH}_{2} \mathrm{SiMe}_{3}\right)(=\mathrm{NPh})$ (ligand) $\left(5^{\prime}\right.$, $9^{\prime}$, and $\left.10^{\prime}\right)^{\wedge}$

\begin{tabular}{clcll}
\hline $\begin{array}{c}\text { compd } \\
\text { no. }\end{array}$ & \multicolumn{1}{c}{ ligand } & $\begin{array}{c}\text { temp } \\
\left({ }^{\circ} \mathrm{C}\right)\end{array}$ & reacn rate & $\begin{array}{c}\text { cis:trans } \\
\text { ratio }^{b}\end{array}$ \\
\hline $\mathbf{5}^{\prime}$ & 8-quinolinolate & 25 & $<1 \mathrm{~min}$ & $100: 0$ \\
$\mathbf{9}^{\prime}$ & OCPh $_{2}(2-\mathrm{py})$ & 25 & ca. $10 \%$ in $24 \mathrm{~h}$ & $88: 12$ \\
& & 70 & $<1 \mathrm{~min}$ & $88: 12$ \\
$\mathbf{1 0}^{\prime}$ & OCH$\left(\mathrm{CMe}_{3}\right)(2-\mathrm{py})$ & 25 & $<5 \%$ in 24 h & \\
& & 70 & ca. $2 \mathrm{~min}$ & $90: 10$
\end{tabular}

a Conditions: $50 \mu \mathrm{mol}$ of alkylidene complex in $1 \mathrm{~mL}$ of benzene added to 250 equiv of norbornene in $10 \mathrm{~mL}$ of benzene (see Experimental Section). ${ }^{b}$ Determined with ${ }^{1} \mathrm{H}$ NMR.

$\left(\Delta \delta_{\mathrm{py}-\mathrm{H}^{8}}=0.73 \mathrm{ppm}\right)$, was obtained. Although the thermal stability of 15 is significantly lower than that of 11-14, so far no pure alkylidene complex has been obtained when a hexane solution of 15 was heated at reflux.

Reactivity of Alkylidene Complexes $5^{\prime}, 9^{\prime}$, and 10' toward Aldehydes and Olefins. The reactivity of the pure tungsten(VI) alkylidene complexes $5^{\prime}, 9^{\prime}$, and $10^{\prime}$ was studied with various substrates. They are very reactive toward aldehydes, reacting in a Wittig-type reaction with the subsequent formation of an olefin and the corresponding tungsten(VI) oxo complex.

Attempts to isolate the new tungsten(VI) phenylimido oxo complexes were unsuccessful. The organic products formed in these reactions were identified $\left({ }^{1} \mathrm{H}\right.$ NMR and $\mathrm{GC} / \mathrm{MS}$ ) as predominantly trans- $\mathrm{Ph}(\mathrm{H}) \mathrm{C}=\mathrm{C}(\mathrm{H}) \mathrm{SiMe}_{3}$ (from the reaction with benzaldehyde) and trans-t-Bu$(\mathrm{H}) \mathrm{C}=\mathrm{C}(\mathrm{H}) \mathrm{SiMe}_{3}$ (from the reaction with pivaldehyde).

All three alkylidene complexes are inert toward linear olefins such as cis-2-pentene and neohexene at room temperature as well as at elevated temperatures $\left(70^{\circ} \mathrm{C}\right)$. However, during an NMR experiment in which ethylene was passed through a benzene solution of $5^{\prime}$, slow formation of vinyltrimethylsilane was observed.

Recently, we reported the synthesis of a new fivecoordinate tungsten complex in which a bidentate arylamine ligand is present (see Figure 2), ${ }^{9}$ and this complex was found to be a very active catalyst in the ring-opening metathesis polymerization reaction of norbornene. The reactivities of $5^{\prime}, 9^{\prime}$, and $10^{\prime}$ toward norbornene differ considerably (see Table 7 ). Complex $5^{\prime}$ is very reactive and polymerizes 250 equiv of norbornene within $1 \mathrm{~min}$ at room temperature, affording all-cis polymeric cyclopentenes. The tungsten(VI) alkylidene complexes $9^{\prime}$ and $10^{\prime}$ react slowly with norbornene at room temperature: they gave $<10 \%$ conversion after $24 \mathrm{~h}$. However, when the temperature was raised to approximately $70^{\circ} \mathrm{C}$, again 250 equiv of norbornene was polymerized within $1 \mathrm{~min}$. In these two cases, as with $5^{\prime}$, norbornene is polymerized in a ring-opening metathesis fashion, yielding polymeric cyclopentene with $\geq 90 \%$ cis-vinylene bonds.

\section{Discussion}

Although some facile routes to active well-defined tungsten alkylidene complexes are known, ${ }^{17}$ the synthesis of tungsten alkylidene complexes is generally difficult and often requires multistep routes. 14,16,17 With the threestep reaction sequence (from commercially available $W(O)$ $\mathrm{Cl}_{4}$ ) described in this paper, alkylidene complexes of a new type are easily accessible. However, in order to obtain

(17) Johnson, L. K.; Virgil, S. C.; Grubbs, R. H.; Ziller, J. W. J. Am. Chem. Soc. 1990, 112, 5384 .
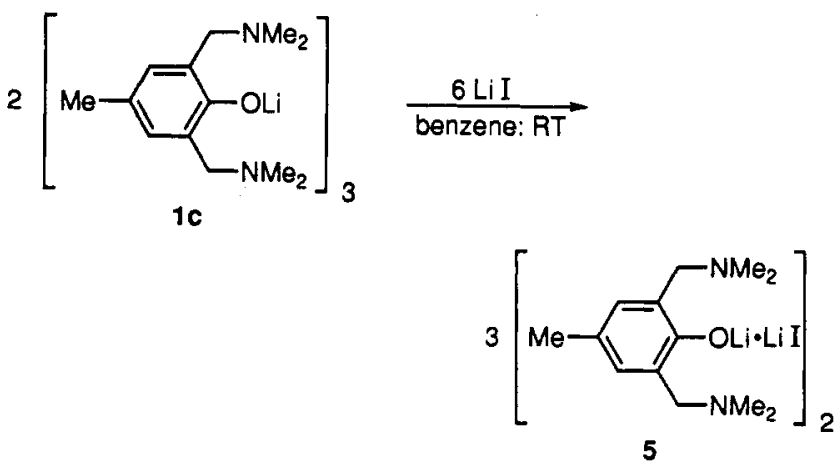

Figure 9. Product of the reaction of lithium "pincerphenolate" with lithium iodide.

pure products, the choice of ligand and reaction conditions is very critical, and the high solubility of the complexes hampered their purification by common procedures such as extraction and recrystallization. Nevertheless, with the correct ligand and conditions, tungsten(VI) phenylimido alkylidene complexes have been obtained in excellent yields. Furthermore, these new complexes show interesting reactivities toward aldehydes (Wittig-type reactivity) and strained cyclic olefins (ROMP).

At first is was not evident why 2 equiv of the lithium "pincer-phenolate" starting material was required for complete reaction with 1 equiv of $\mathrm{W}\left(\mathrm{CH}_{2} \mathrm{SiMe}_{3}\right)_{3} \mathrm{Cl}$ (=NPh). We now think that 1 equiv of the lithium pincerphenolate is consumed in the formation of a 1:1 adduct with $\mathrm{LiCl}$, liberated during the reaction. Apparently, this adduct is too stable to react with the chloride $\mathrm{W}\left(\mathrm{CH}_{2}\right.$ $\left.\mathrm{SiMe}_{3}\right)_{3} \mathrm{Cl}\left(=\mathrm{NPh}\right.$ ) (cf. for the formation of $\mathrm{WCl}_{3}\left[\mathrm{OC}_{6} \mathrm{H}_{2}\right.$ $\left.\left(\mathrm{CH}_{2} \mathrm{NMe}_{2}\right)_{2}-2,6-\mathrm{Me}-4\right](=\mathrm{NPh})$ starting with WCl - $^{-}$ $(=\mathrm{NPh})\left(\mathrm{OEt}_{2}\right)$ just 1 equiv of lithium pincer-phenolate is required).11a The formation of such a 1:1 adduct was recently established by us with the $\mathrm{X}$-ray structure of $\left.\left[\mathrm{Li}_{2} \mathrm{I}_{\{} \mathrm{OC}_{6} \mathrm{H}_{2}\left(\mathrm{CH}_{2} \mathrm{NMe}\right)_{2}-2,6-\mathrm{Me}-4\right\}\right]_{2}$, which was obtained from the reaction of lithium pincer-phenolate with $\mathrm{LiI}$ in benzene $^{18}$ (see Figure 9).

During the last decade it has been found that the formation of an alkylidene complex via a $\mathrm{H}_{\alpha}$-abstraction reaction strongly depends on the steric as well as the electronic properties of the precursor complex. ${ }^{4,19}$ In the present study it was found that reactions of $\mathrm{W}\left(\mathrm{CH}_{2} \mathrm{SiMe}_{3}\right)_{3}$ $\mathrm{Cl}(=\mathrm{NPh})(1)$ with the lithium salts of the mono-o- $\mathrm{CH}_{2-}$ $\mathrm{NMe}_{2}$-substituted phenoxide $\mathrm{a}$ and the three arenethiolate ligands $\mathbf{d}-\mathbf{f}$ give rise to the formation of the transmetalation products only, the tris[(trimethylsilyl)methyl]tungsten complexes 3 and 6-8. These trialkyltungsten complexes could not be isolated in the case of bis-o- $\mathrm{CH}_{2} \mathrm{NMe}_{2}-$ substituted pincer-phenolate (b) and 8-quinolinolate (c) derivatives, as the tris[(trimethylsilyl)methyl] tungsten analogs react further in an $\mathrm{H}_{\alpha}$-abstraction reaction that affords the corresponding tungsten(VI) alkylidene complexes $4^{\prime}$ and $5^{\prime}$. The pincer-phenolate $b$, and to a lesser extent ligand $\mathbf{c}$, give rise to much more steric repulsion than the ligands $a$ and $\mathbf{d}-\mathbf{f}$. Ligand $\mathbf{c}$ will form a fivemembered ring upon $\mathrm{W}-\mathrm{N}$ bond formation, whereas the ortho-substituted phenoxide will form a six-membered chelate ring. Moreover, the oxygen atom in ligand $\mathbf{c}$ is a weaker electron donor than those in the phenoxide ligands and the sulfur atoms in the arenethiolate ligands. Thus,

(18) van der Schaaf, P. A.; Hogerheide, M. P.; Grove, D. M.; Spek, A. L.; Van Koten, G. J. Chem. Soc., Chem. Commun. 1992, 1703.

(19) Nugent, W. A.; Mayer, J. M. Metal-Ligand Multiple Bonds; Wiley: New York, 1988. 
the initially formed precursor will be more electron deficient and therefore be more susceptible to an internal $\mathrm{H}_{\alpha}$-abstraction reaction (vide infra).

The series of 2-pyridylmethoxide ligands ( $\left[O C R^{1} R^{2}(2-\right.$ py)]; $\mathbf{g}-\mathbf{m})$ provides an even better demonstration that, besides the steric properties of the alkylidene precursor complex, the electronic properties are also very important. In this system the $\mathrm{R}^{1}$ and $\mathrm{R}^{2}$ substituents on $\mathrm{C}_{\alpha}$ of the ligand can be easily varied, making these ligands readily tunable. This tuning has enabled the isolation and characterization of alkylidenes and their precursor complexes. As a consequence of the electron-donating properties of the $\mathrm{C}_{\alpha}$ substituents, the relative basicity of the methoxide ligands $\mathbf{j}$ and $\mathbf{k}$, which are present in complexes 9 and 10 , is assumed to be $\mathrm{OCH}\left(\mathrm{CMe}_{3}\right)(2-\mathrm{py})(\mathbf{k})>\mathrm{OCPh}_{2}$ (2-py) (j).

Complex 10 , containing ligand $\mathbf{k}$, is a five-coordinate species in which the methoxide is monodentate $\mathrm{O}$-bonded. The metal center in this complex is less acidic as a result of the basicity of $\mathbf{k}$, and therefore, no pyridyl-tungsten bond formation occurs. In the molecular structure of 9 , containing the less basic ligand $\mathbf{j}$, the pyridyl group does coordinate to the more acidic tungsten center.

In conclusion, the phenoxide ligands $a$ and $b$ show the effect of steric factors on the alkylidene precursor complexes, while the two 2-pyridylmethoxide ligands $\mathbf{j}$ and $\mathbf{k}$ do the same for electronic factors.

It is generally accepted that the metal atom in a highvalent early-transition-metal complex decreases in electron deficiency when an alkylidene functionality is formed from two alkyl groups via an $\mathrm{H}_{\alpha}$-abstraction reaction. ${ }^{19}$ These electronic advantages for a $\mathrm{d}^{0}$-metal complex are well illustrated by the two molecular structures of 9 and $9^{\prime}$. The phenylimido group, which is present in both compounds, is a good tool for determining the electron deficiency within the molecules, ${ }^{19}$ since it is known that the angle around the imido nitrogen is strongly influenced by the electron donation of this group. These angles are $173.2(13)$ and $159.3(3)^{\circ}$ for the trialkyltungsten species 9 and the alkylidene complex $9^{\prime}$, respectively. The enlarged angle in 9 is the result of strong $\pi$-electron donation of the imido nitrogen to the metal center. The angle in $9^{\prime}$ of $159.3(3)^{\circ}$ is comparable with that found in a fivecoordinated phenylimido alkylidene complex reported earlier, viz. $162.6(13)^{\circ}$ in $\mathrm{W}\left(\mathrm{C}_{6} \mathrm{H}_{4} \mathrm{CH}_{2} \mathrm{NMe}_{2}\right.$-2)$\left(=\mathrm{CHSiMe}_{3}\right)\left(\mathrm{CH}_{2} \mathrm{SiMe}_{3}\right)(=\mathrm{NPh}),{ }^{9}$ and the angle in complex 9 is very similar to those found in a six-coordinate tungsten phenoxide, viz. $172.3(3)^{\circ}$ in $\mathrm{WCl}_{3}(=\mathrm{NPh})$ $\left[\mathrm{OC}_{6} \mathrm{H}_{2}\left(\mathrm{CH}_{2} \mathrm{NMe}_{2}\right)_{2}-2,6-\mathrm{Me}-4\right]$, $11 \mathrm{a}$ and in a six-coordinate aryltungsten alkoxide, viz. $170.4(7)^{\circ}$ in $\mathrm{W}\left(\mathrm{C}_{6} \mathrm{H}_{4} \mathrm{CH}_{2} \mathrm{NMe}_{2-}\right.$ 2) $\mathrm{Cl}_{2}(=\mathrm{NPh})\left(\mathrm{OCMe}_{3}\right){ }^{20}$

Complex 10 contains ligand $\mathbf{k}$, in which $\mathrm{C}_{\alpha}$ is a chiral center, and upon formation of a tungsten(VI) alkylidene complex two diastereoisomers are possible. Therefore, together with the two rotamers (syn and anti) possible for the alkylidene fragment, four different species could be expected. These four species are observed (by ${ }^{1} \mathrm{H}$ NMR spectroscopy), though two are present as only approximately $3 \%$ of the total. This selectivity is most probably sterically controlled by the bulky tert-butyl group present on the $\mathrm{C}_{\alpha}$ of the methoxide ligand.

The significant different of the chemical shifts of $\mathrm{H}^{7}$ for $5^{\prime}$ and $\mathrm{H}^{6}$ for $9^{\prime}$ and $10^{\prime}$ between the syn and the anti

(20) van der Schaaf, P. A.; Boersma, J.; Kooijman, H.; Spek, A. L.; van Koten, G. Organometallics 1993, 12, 4334. rotamers of these alkylidene complexes is noteworthy. In all three complexes there is a significant downfield shift for that hydrogen atom of the syn rotamers relative to that in the parent alcohol. Such a significant shift difference for these hydrogen atoms is absent in the anti rotamers. These data suggest that the syn rotamers are five-coordinate as a result of intramolecular $\mathrm{W}-\mathrm{N}$ coordination, whereas the anti rotamers are four-coordinate species. In the syn rotamer the alkyl group of the alkylidene function, in these complexes $\mathrm{SiMe}_{3}$, is pointed toward the phenylimido group. ${ }^{13}$ In addition, in the anti rotamer this trimethylsilyl group points away from the phenylimido group. When the geometry of the molecular structure of $9^{\prime}$ is considered (Figure 6 represents the $s y n$ rotamer of $9^{\prime}$ ), the trimethylsilyl group in an ant $i$ rotamer would lead to considerable steric hindrance with the substituents bonded to the $\mathrm{C}_{\alpha}$-atom of the chelating ligand. Therefore, these steric arguments are also in accordance with our proposal that only the syn rotamers are fivecoordinate and that the potentially bidentate ligands in the anti rotamers are monodentate bonded.

The Wittig-type reactivity of the tungsten alkylidene complexes $5^{\prime}, 9^{\prime}$, and $10^{\prime}$ toward aldehydes and ketone was not unexpected. This type of reactivity has been welldocumented over recent years for tungsten, tantalum, and titanium alkylidene complexes, ${ }^{21}$ and applications within organic chemistry are known. ${ }^{22}$ Recently, even intermediates in this reaction have been isolated and fully characterized. ${ }^{23}$ An important result from our reactivity studies is that the alkylidene unit is not blocked by the intramolecularly coordinating ligand and remains accessible for reactions. We can furthermore conclude that the inertness of these alkylidene complexes toward linear olefins is not the direct result of the five-coordinate geometry, since in solution four-coordinate species are also present. Therefore, this lack of reactivity is most likely caused by electronic rather than by steric properties of the alkylidene complex. It is remarkable that these alkylidene complexes are inert toward cis-2-pentene and neohexene and, up to now, we have no reasonable explanation for this result.

The influence of electronic properties, which are found to be very important for the reactivity of alkylidene complexes, is also reflected in the reactivity of $5^{\prime}, 9^{\prime}$, and $10^{\prime}$ toward strained cyclic olefins. Complex $5^{\prime}$, containing the 8-quinolinolate ligand, reacts much faster with norbornene than complexes $9^{\prime}$ and $10^{\prime}$, in which a 2-pyridylmethoxide ligand is bonded to the metal center. The electron-donating character of the 2-pyridylmethoxide ligand, an alkoxide oxygen combined with a $\pi$-donating pyridyl nitrogen, is greater than that of the 8-quinolinolate ligand, in which the oxygen atom is a weaker Lewis base. Therefore, the lower reactivity of $9^{\prime}$ and $10^{\prime}$ (these complexes give a fast polymerization reaction with norbornene only at elevated temperatures $\left(\mathrm{ca} .70^{\circ} \mathrm{C}\right)$ ) can be

(21) (a) Tebbe, F. N.; Parshall, G. W.; Reddy, G. S. J. Am. Chem. Soc. 1978, 100, 3611. (b) Pine, S.; Zahler, R.; Evans, D. A.; Grubbs, R. H. J. Am. Chem. Soc. 1983, 105, 1664. (c) Cannizzo, L. F.; Grubbs, R. H. J. Org. Chem. 1985, 50, 2386. (d) Kauffmann, T.; Enk, M.; Kaschube, W. Toliopoulos, E.; Wingbergmuehle, D. Angew. Chem., Int.Ed. Engl. 1986, 25, 910. (e) Schrock, R. R. J. Am. Chem. Soc. 1976, 98, 5399.

(22) (a) Brown-Wensly, K. A.; Buchwald, S. L.; Cannizzo, L.; Clawson, L.; Ho, S.; Weinhardt, D.; Stille, J. R.: Straus, D.; Grubbs, R. H. Pure Appl. Chem. 1983, 55, 1733. (b) Rajan Babu, T. B.; Reddy, G. S. J. Org. Chem. 1986, 51, 5458. (c) Aguero, A.; Kress, J.; Osborn, J. A. J. Chem. Soc., Chem. Commun. 1985, 793. (d) Aguero, A.; Kress, J.; Osborn, J. A. J. Chem. Soc., Chem. Commun. 1986, 531.

(23) Bazan, G. C.; Schrock, R. R. Organometallics 1991, 10, 1062. 
explained in terms of Lewis acidity of the metal centers. The Lewis acidity of $9^{\prime}$ and $10^{\prime}$ appears to be too high for the metals to interact readily with the olefinic double bond of a norbornene molecule, whereas the metal center in $\mathbf{5}^{\prime}$ is less Lewis acidic and therefore can have a better interaction with these double bonds with the subsequent formation of a polymer.

\section{Conclusions}

The results presented in this paper show that with potentially chelating aryloxide and alkoxide ligands new tungsten(VI) alkylidene complexes are easily accessible in excellent yields in a three-step reaction route. However, the choice of ligand appears to be very critical, as obtaining pure materials from a reaction mixture containing impurities is very difficult. The alkylidene complexes obtained in this way are present in solution as a mixture of five-coordinate species, as a result of intramolecular W-N coordination, and four-coordinate species, in which this $\mathrm{W}-\mathrm{N}$ coordination is absent. The chemical shift of the hydrogen bonded at the ortho position with respect to the potentially coordinating nitrogen atom is an excellent tool for determining the presence or absence of this type of intramolecular W-N coordination. These new alkylidene complexes are inert toward linear olefins but can polymerize strained cyclic olefins in a ring-opening metathesis reaction. Moreover, by tuning the alkoxide ligand, it is possible to synthesize and isolate alkylidene precursor complexes which upon heating give (via a clean $\mathrm{H}_{\alpha}$-abstraction reaction) the corresponding alkylidene complexes quantitatively. These complexes may be of particular interest in special applications. For example, a solution of a cyclic olefin and an alkylidene precursor complex that is stable at low (e.g. room) temperature but that polymerizes the olefin at higher temperatures is of more than academic value.

\section{Experimental Section}

General Considerations. All reactions were carried out under an atmosphere of dry, deoxygenated dinitrogen, using standard Schlenk techniques. Solvents were stored over sodium benzophenone ketyl and distilled under nitrogen prior to use. Commercially available reagents were used as supplied, whereas $\mathrm{WCl}_{4}(=0),{ }^{24} \mathrm{WCl}_{4}(=\mathrm{NPh})\left(\mathrm{OEt}_{2}\right),{ }^{25} \mathrm{Zn}\left(\mathrm{CH}_{2} \mathrm{SiMe}_{3}\right)_{2},{ }^{26} \mathrm{~W}\left(\mathrm{CH}_{2^{-}}\right.$ $\left.\mathrm{SiMe}_{3}\right)_{3} \mathrm{Cl}(=\mathrm{NPh})(1),{ }^{\mathrm{gb}} \mathrm{WCl}_{3}(=\mathrm{NPh})\left(\mathrm{OC}_{6} \mathrm{H}_{3} \mathrm{Me}_{2}-3,5\right)\left(\mathrm{OEt}_{2}\right)^{,{ }_{11 \mathrm{a}}}$ 2-((dimethylamino)methyl)phenol, 27,28 2,6-bis ((dimethylamino)methyl)-4-methylphenol, 27,28 $\mathrm{Me}_{3} \mathrm{SiS}\left[(R)-\mathrm{C}_{6} \mathrm{H}_{4} \mathrm{CH}(\mathrm{Me}) \mathrm{NMe}_{2}-\right.$ 2], ${ }^{29} \mathrm{Li}\left(\mathrm{OC}_{6} \mathrm{H}_{4} \mathrm{CH}_{2} \mathrm{NMe}_{2}-2\right),{ }^{28}$ and $\mathrm{Li}\left[\mathrm{OC}_{6} \mathrm{H}_{2}\left(\mathrm{CH}_{2} \mathrm{NMe}_{2}\right)_{2}-2,6-\mathrm{Me}-\right.$ $4{ }^{28}$ were synthesized by following literature procedures. Sodium 8-quinolinolate was prepared from 8-hydroxyquinoline and sodium hydride in THF. $\mathrm{Me}_{3} \mathrm{SiS}\left(\mathrm{C}_{10} \mathrm{H}_{6} \mathrm{NMe}_{2}-8\right)$ and $\mathrm{Me}_{3} \mathrm{SiS}-$ $\left(\mathrm{C}_{6} \mathrm{H}_{4} \mathrm{NMe}_{2}-2\right)$ were prepared according to the literature procedure described for $\mathrm{Me}_{3} \mathrm{SiS}\left[(R)-\mathrm{C}_{6} \mathrm{H}_{4} \mathrm{CH}(\mathrm{Me}) \mathrm{NMe}_{2}-2\right] .{ }^{29}$ The

(24) (a) Gibson, V. C.; Kee, T. P.; Shaw, A. Polyhedron 1988, 7, 579. (b) Schrock, R. R.; DuPue, R. T.; Feldman, J.; Yap, K. B.; Yang, D. C.; Davis, W. M.; Park, L.; DiMare, M.; Schofield, M.; Anhaus, J.; Walborsky, E.; Evitt, E.; Kräger, C.; Betz, P. Organometallics 1990, 9, 2262.

(25) Pedersen, S. F.; Schrock, R. R. J. Am. Chem. Soc. 1982, 104, 7483 (26) $\mathrm{Zn}\left(\mathrm{CH}_{2} \mathrm{SiMe}_{3}\right)_{2}$ was prepared from $\mathrm{LiCH}_{2} \mathrm{SiMe}_{3}$ and $\mathrm{ZnCl}_{2}$ in diethyl ether. $\mathrm{LiCH}_{2} \mathrm{SiMe}_{3}$ was prepared according to: Sommer, L. $\mathrm{H}$.; Mitch, F. A.; Goldberg, G. M. J. Am. Chem. Soc. 1949, 71, 2746.

(27) (a) Bayer \& Co. Deutsches Reichspatent 89979 and 92309; Frdl. 1895, 4, 103. (b) Décombe, J. C.R. Hebd. Seances Acad. Sci. 1933, 196 , 866 .

(28) van der Schaaf, P. A.; Jastrzebski, J. T. B. H.; Hogerheide, M. P.; Smeets, W. J. J.; Spek, A. L.; Boersma, J.; van Koten, G. Inorg. Chem. $1993,32,4111$.

(29) Knotter, D. M.; Janssen, M. D.; Grove, D. M.; Smeets, W. J. J.; Horn, E.; Spek, A. L.; van Koten, G. Inorg. Chem. 1991, 30, 4361. lithium arenethiolates were obtained quantitatively as white solids by the reaction of methyllithium with the trimethylsilyl thioethers in $\mathrm{Et}_{2} \mathrm{O}$. 2-Pyridylcarbinol is commercially available and was used as supplied. The $\alpha$-substituted derivatives of this alcohol were prepared either via literature procedures or via analogous reactions. ${ }^{30}$ The corresponding lithium alcoholates were prepared by equimolar reactions with $n$-BuLi in hexane at $0{ }^{\circ} \mathrm{C}$. ${ }^{1} \mathrm{H}$ and ${ }^{13} \mathrm{C}$ NMR spectra were recorded on a Bruker $\mathrm{AC}$ 200 or AC 300 spectrometer in benzene- $d_{6}$ at $25^{\circ} \mathrm{C}$, unless noted otherwise. Elemental analyses were carried out by the Mikroanalytisches Laboratorium Dornis und Kolbe, Mülheim a.d. Ruhr, Germany.

Starting Materials. The lithium alkoxides and thiolates used in this paper are insoluble in solvents such as benzene. These compounds were extensively washed with pentane to remove excess alcohol or thioether. The purity of these compounds was established by elemental analysis. However, the new lithium salts derived from $\mathbf{k}-\mathrm{m}$ are soluble in benzene, and for these compounds NMR data are given.

Li[OCH(CMes)(2-py)]. ' ${ }^{1} \mathrm{H}$ NMR: $\delta 8.19$ (d, 1, py H'); 6.72, $6.42(\mathrm{t}, \mathrm{m}, 3$, py H$) ; 4.54\left(\mathrm{~s}, 1, \mathrm{CH}\left(\mathrm{CMe}_{3}\right)\right) ; 1.19\left(\mathrm{~s}, 9, \mathrm{CH}\left(\mathrm{CMe}_{3}\right)\right)$. ${ }^{13} \mathrm{C}$ NMR: $\delta 170.7$ (py C ${ }^{2}$ ); 147.3 (py $\mathrm{C}^{6}$ ); 133.9, 122.9, 120.1 (py C); $87.2(\mathrm{OC}) ; 37.9\left(\mathrm{CH}\left(\mathrm{CMe}_{3}\right)\right) ; 27.4\left(\mathrm{CH}\left(\mathrm{CMe}_{3}\right)\right)$. Anal. Calcd for $\mathrm{C}_{10} \mathrm{H}_{14} \mathrm{NOLi}$ : C, $70.17 ; \mathrm{H}, 8.24 ; \mathrm{N}, 8.18$. Found: $\mathrm{C}, 70.18 ; \mathrm{H}$, $8.22 ; \mathrm{N}, 8.27$.

$\mathrm{Li}\left[\mathrm{OCMe}\left(\mathrm{CMe}_{3}\right)(2-\mathrm{py})\right]$. ${ }^{1} \mathrm{H} \mathrm{NMR}\left(\mathrm{C}_{6} \mathrm{D}_{8} ; 70^{\circ} \mathrm{C}\right): \delta 8.43(\mathrm{~d}$, 1 , py H$\left.{ }^{6}\right) ; 6.98-6.62\left(\mathrm{~m}, 3\right.$, py H); 1.43 (s, 3, $\mathrm{CMeCMe}_{3}$ ); 1.07 (s, 9, $\mathrm{CMeCMe}_{3}$ ). Anal. Calcd for $\mathrm{C}_{11} \mathrm{H}_{16} \mathrm{NOLi}$ C, 71.34; $\mathrm{H}, 8.71$; N, 7.56. Found: C, 71.29; H, 8.75; N, 7.59.

Li[O-j-Pr $([2]-p y)] .{ }^{1} \mathrm{H}$ NMR $\left(\mathrm{C}_{8} \mathrm{D}_{6} ; 70^{\circ} \mathrm{C}\right): \delta 8.55$ (d, 1 , py $\mathrm{H}^{6}$ ); 7.15-6.62 (m, 3, py H); 2.34 (dq, 2, $\mathrm{CHMe}$ ); 1.06, 0.90 (dd, 12, $\mathrm{CHMe}$ ).

$\mathrm{W}\left(\mathrm{CH}_{2} \mathrm{SiMe}_{3}\right)_{2} \mathrm{Cl}(=\mathrm{NPh})\left(\mathrm{OCMe}_{3}\right)(2)$. This complex was prepared via a procedure similar to that described for the bis(neopentyl) analog. ${ }^{25} \mathrm{Bis}$ ((trimethylsilyl)methyl)zinc (5.78 g, 24.1 mmol) in $\mathrm{CH}_{2} \mathrm{Cl}_{2}(15 \mathrm{~mL}$ ) was added slowly to a vigorously stirred solution of $\left[\mathrm{WCl}_{4}(=\mathrm{NPh})\left(\mathrm{OCMe}_{3}\right)\right]\left[\mathrm{NEt}_{4}\right](14.96 \mathrm{~g}, 24.1 \mathrm{mmol})$ in $\mathrm{CH}_{2} \mathrm{Cl}_{2}(60 \mathrm{~mL})$. After removal of the volatiles in vacuo, the compound was crystallized from a saturated pentane solution at $-30^{\circ} \mathrm{C}$. The product was obtained as a yellow solid $(11.4 \mathrm{~g} ; 85 \%)$. ${ }^{1} \mathrm{H}$ NMR: $\delta 7.25$ (d, $\left.2,{ }^{3} J_{\mathrm{H}_{0} \mathrm{H}_{m}}=7.8 \mathrm{~Hz}, 0-\mathrm{H} \mathrm{NPh}\right) ; 7.13\left(\mathrm{t}, 1, J_{\text {obed }}\right.$ $=8.1 \mathrm{~Hz}, m-\mathrm{H} \mathrm{NPh}) ; 6.85\left(\mathrm{t}, 1,{ }^{3} J_{\mathrm{H}_{p} \mathrm{H}_{m}}=7.5 \mathrm{~Hz}, p-\mathrm{H} \mathrm{NPh}\right) ; 2.80$ $\left(\mathrm{d}, 2,{ }^{2} J_{\mathrm{H}_{\mathrm{A}} \mathrm{H}_{\mathrm{B}}}=8.1 \mathrm{~Hz},{ }^{2} J_{\mathrm{WH}}=9.1 \mathrm{~Hz}, \mathrm{CH}_{\mathrm{A}} \mathrm{H}_{\mathrm{B}} \mathrm{Si}\right) ; 2.13\left(\mathrm{~d}, 2,{ }^{2} J_{\mathrm{H}_{\mathrm{B}} \mathrm{H}_{\mathrm{A}}}\right.$ $\left.=8.1 \mathrm{~Hz},{ }^{2} J_{\mathrm{WH}}=8.8 \mathrm{~Hz}, \mathrm{CH}_{A} H_{B} \mathrm{Si}\right) ; 1.23\left(\mathrm{~s}, 9, \mathrm{OCMe}_{3}\right) ; 0.24(\mathrm{~s}$, 18, $\left.\mathrm{SiMe}_{3}\right)$. ${ }^{13} \mathrm{C}$ NMR: $\delta 153.0\left(\mathrm{C}_{i p e o} \mathrm{NPh}\right) ; 128.8,127.6,126.4$ $(\mathrm{NPh}) ; 87.6\left(\mathrm{OCMe}_{3}\right) ; 70.1\left({ }^{1} J_{\mathrm{WC}}=79.5 \mathrm{~Hz}, \mathrm{CH}_{2} \mathrm{Si}\right) ; 31.4\left(\mathrm{OCMe}_{3}\right)$; 2.5 ( $\mathrm{SiMe}_{3}$ ). Anal. Calcd for $\mathrm{C}_{18} \mathrm{H}_{36} \mathrm{ClNOSi}_{2} \mathrm{~W}: \mathrm{C}, 38.75 ; \mathrm{H}, 6.50$; $\mathrm{N}, 2.51$. Found: $\mathrm{C}, 38.84 ; \mathrm{H}, 6.59 ; \mathrm{N}, 2.56$.

$\mathrm{W}\left(\mathrm{CH}_{2} \mathrm{SiMe}_{3}\right)_{2} \mathrm{Cl}(=\mathrm{NPh})\left(\mathrm{OC}_{6} \mathrm{H}_{8} \mathrm{Me}_{2}-3,5\right)$. This complex was prepared by a modification of the procedure described for $\mathrm{W}\left(\mathrm{CH}_{2} \mathrm{SiMe}_{3}\right)_{2} \mathrm{Cl}(=\mathrm{NPh})\left(\mathrm{OCMe}_{3}\right)$. An equimolar amount of $\mathrm{Et}_{4}-$ $\mathrm{NCl}$ was added as a solid to a solution of $\mathrm{WCl}_{3}(=\mathrm{NPh})\left(\mathrm{OC}_{8} \mathrm{H}_{3}\right.$ $\left.\mathrm{Me}_{2}-3,5\right)\left(\mathrm{OEt}_{2}\right)(10.60 \mathrm{~g}, 18.40 \mathrm{mmol})$ in $\mathrm{CH}_{2} \mathrm{Cl}_{2}(50 \mathrm{~mL})$. After the mixture was stirred for $15 \mathrm{~min}$, a solution of $\mathrm{Zn}\left(\mathrm{CH}_{2} \mathrm{SiMe}_{3}\right)_{2}$ (4.47 $\mathrm{g}, 18.64 \mathrm{mmol})$ in $\mathrm{CH}_{2} \mathrm{Cl}_{2}(40 \mathrm{~mL})$ was added dropwise to the dark purple suspension. During addition of the zinc compound the reaction mixture turned brown. After $2 \mathrm{~h}$ the volatiles were removed in vacuo and the resulting residue was extracted with hexane $(3 \times 50 \mathrm{~mL})$. The combined hexane fractions were concentrated in vacuo to $20 \mathrm{~mL}$ and cooled to -30 ${ }^{\circ} \mathrm{C}$. The product was obtained as a light brown solid $(9.3 \mathrm{~g}, 84 \%)$. ${ }^{1} \mathrm{H}$ NMR: $\delta 7.00-6.91(\mathrm{~m}, 4, \mathrm{Ar} \mathrm{H}) ; 6.80$ (t, 1, p-H NPh); 6.69 (s, 2, o-H OAr); $6.45(\mathrm{~s}, 1, p-\mathrm{H} \mathrm{OAr}) ; 2.77\left(\mathrm{~d}, 2,{ }^{2} J_{\mathrm{H}_{\mathrm{A}} \mathrm{H}_{\mathrm{B}}}=7.7 \mathrm{~Hz},{ }^{2} J_{\mathrm{WH}}\right.$ $\left.=9.4 \mathrm{~Hz}, \mathrm{CH}_{\mathrm{A}} \mathrm{H}_{\mathrm{B}} \mathrm{Si}\right) ; 2.48\left(\mathrm{~d}, 2,{ }^{2} J_{\mathrm{Hg}_{\mathrm{B}}}=7.7 \mathrm{~Hz},{ }^{2} J_{\mathrm{WH}}=9.4 \mathrm{~Hz}\right.$, $\left.\mathrm{CH}_{\mathrm{A}} \mathrm{H}_{\mathrm{B}} \mathrm{Si}\right) ; 2.00$ (s, 6, $\left.\mathrm{Me}_{2}-3,5\right) ; 0.23$ (s, 18, $\mathrm{SiMe}_{3}$ ). ${ }^{13} \mathrm{C}$ NMR: $\delta 166.9\left(\mathrm{C}_{\text {ipso }} \mathrm{OAr}\right) ; 151.4\left(\mathrm{C}_{\text {ipeo }} \mathrm{NPh}\right) ; 139.6,128.7-127.1,125.5$, 118.1, 117.4 (Ar C); $75.9\left({ }^{1} J_{\mathrm{WC}}=81.5 \mathrm{~Hz}, \mathrm{CH}_{2} \mathrm{Si}\right) ; 21.1\left(\mathrm{Me}_{2}-3,5\right)$;

(30) (a) Proost, W.; Wibaut, J. P. Recl. Trav. Chim. Pays-Bas 1940, 59, 971. (b) Wibaut, J. P.; De Jonge, A. P.; Van der Voort, H. G. P.; Otto, P. Ph. H. L. Recl. Trav. Chim. Pays-Bas 1951, 70, 1054. (c) Luz, W. D. Fallab, S.; Erlenmeyer, H. Helv. Chim. Acta 1955, 38, 1114. (d) Davies, A. G.; Keyon, J.; Thaker, K. J. Chem. Soc. 1956, 3394. 
2.1 (SiMe ${ }_{3}$ ). Anal. Calcd for $\mathrm{C}_{22} \mathrm{H}_{36} \mathrm{CINOSi}_{2} \mathrm{~W}: \mathrm{C}, 43.60 ; \mathrm{H}, 5.99$; $\mathrm{N}, 2.31$. Found: $\mathrm{C}, 43.48 ; \mathrm{H}, 6.05 ; \mathrm{N}, 2.42$.

Products. W( $\left.\mathrm{CH}_{2} \mathrm{SiMe}_{3}\right)_{3}(=\mathrm{NPh})\left(\mathrm{OC}_{6} \mathrm{H}_{4} \mathrm{CH}_{2} \mathrm{NMe}_{2}-2\right)$ (3). $\mathrm{Li}\left(\mathrm{OC}_{6} \mathrm{H}_{4} \mathrm{CH}_{2} \mathrm{NMe}_{2}-2\right)(0.90 \mathrm{~g}, 5.7 \mathrm{mmol})$ was added as a solid to a stirred solution of $1(3.15 \mathrm{~g}, 5.5 \mathrm{mmol})$ in diethyl ether (60 $\mathrm{mL}$ ) at ambient temperature. The turbid reaction mixture was stirred overnight. The volatiles were removed in vacuo, and the resulting residue was extracted with pentane $(2 \times 50 \mathrm{~mL})$. The combined pentane fractions were dried in vacuo, leaving a brownish oil ( $3.47 \mathrm{~g}, 92 \%$ ). ${ }^{1} \mathrm{H}$ NMR: $\delta 7.78,7.48,7.20-7.00$ (d, $\mathrm{d}, \mathrm{m}, 8, \mathrm{Ar} \mathrm{H}) ; 6.90$ (t, 1, p-H NPh); 3.87 (s, 2, $\left.\mathrm{CH}_{2} \mathrm{~N}\right) ; 2.32$ (s, $\left.6, \mathrm{NMe}_{2}\right) ; 1.71\left(\mathrm{~s}, 6,{ }^{2} J_{\mathrm{WH}}=8.6 \mathrm{~Hz}, \mathrm{CH}_{2} \mathrm{Si}\right) ; 0.17\left(\mathrm{~s}, 27, \mathrm{SiMe}_{3}\right)$. ${ }^{13} \mathrm{C}$ NMR: $\delta 162.5\left(\mathrm{C}_{i p s o} \mathrm{OAr}\right) ; 155.6\left(\mathrm{C}_{\text {ipso }} \mathrm{NPh}\right) ; 131.1,128.7-$ $127.2,126.0,120.5,119.5(\mathrm{Ar} \mathrm{C}) ; 63.7\left({ }^{1} J_{\mathrm{WC}}=77.2 \mathrm{~Hz}, \mathrm{CH}_{2} \mathrm{Si}\right)$; $60.1\left(\mathrm{CH}_{2} \mathrm{~N}\right) ; 46.1\left(\mathrm{NMe}_{2}\right) ; 2.4\left(\mathrm{SiMe}_{3}\right)$.

$\mathrm{W}(=\mathrm{CHSiMe})\left(\mathrm{CH}_{2} \mathrm{SiMe}_{3}\right)(=\mathrm{NPh})\left[\mathrm{OC}_{6} \mathrm{H}_{2}\left(\mathrm{CH}_{2} \mathrm{NMe}_{2}\right)_{2}-\right.$ 2,6-Me-4] $\left(4^{\prime}\right)$. This reaction was carried out in a similar way as described for 3 , except that 2 equiv of the lithium pincerphenolate $\mathrm{Li}\left[\mathrm{OC}_{6} \mathrm{H}_{2}\left(\mathrm{CH}_{2} \mathrm{NMe}_{2}\right)_{2}-2,6-\mathrm{Me}-4\right]$ must be added. An alternative procedure, in which the reaction was performed at low temperature $\left(-78^{\circ} \mathrm{C}\right)$ and after which the reaction mixture was warmed to room temperature before workup, improved neither the yield nor the purity (see text). Selected ${ }^{1} \mathrm{H}$ NMR data: $\delta 11.50\left(\mathrm{H}_{\alpha}\right.$ anti rotamer, ${ }^{2} J_{\mathrm{WH}}$ not obsd); $10.81\left(\mathrm{H}_{\alpha}\right.$ syn rotamer, ${ }^{2} J_{\mathrm{WH}}=12.0 \mathrm{~Hz}$ ) (syn:anti ratio $4: 6$ ).

$\mathbf{W}\left(=\mathrm{CHSiMe}_{3}\right)\left(\mathrm{CH}_{2} \mathrm{SiMe}_{3}\right)(=\mathrm{NPh})(8$-quin $)\left(5^{\prime}\right)$. This reaction was performed in much the same way as described for 3 , using THF as solvent (sodium 8-quinolinolate is soluble in THF). The product was obtained as a brown oil which, according to its NMR spectrum, was almost pure. Attempts to purify this oil by recrystallization from a minimum of pentane at low temperature $\left(-30^{\circ} \mathrm{C}\right)$ were unsuccessful. This complex is obtained as a mixture of two rotamers (with a syn:anti ratio of $7: 3$ ). Selected data are as follows. ${ }^{1} \mathrm{H} \mathrm{NMR}$ (syn rotamer): $\delta 10.65\left({ }^{2} J_{\mathrm{WH}}=12.0 \mathrm{~Hz}, \mathrm{H}_{\alpha}\right)$; 8.53 (d, $\mathrm{H}^{7}$ quin); 7.3-6.5 (Ar H); 6.32 (dd, $\mathrm{H}$ quin); 1.33 ( $\mathrm{s},{ }^{2} J_{\mathrm{WH}}$ $\left.=8.2 \mathrm{~Hz}, \mathrm{CH}_{2} \mathrm{Si}\right) ; 0.18\left(\mathrm{SiMe}_{3}\right) .{ }^{1} \mathrm{H} \mathrm{NMR}$ (anti rotamer): $\delta 11.70$ ( ${ }^{2} J_{\text {WH }}$ not obsd, $\mathrm{H}_{\alpha}$ ); 8.16 (d, $\mathrm{H}^{7}$ quin); 7.3-6.5 (Ar H); 6.03 (dd, H quin); $1.70\left(\mathrm{~d},{ }^{2} J_{\mathrm{H}_{\mathrm{A}} \mathrm{H}_{\mathrm{B}}}=11.4 \mathrm{~Hz},{ }^{2} J_{\mathrm{WH}}=6.9 \mathrm{~Hz}, \mathrm{CH}_{A} \mathrm{H}_{\mathrm{B}} \mathrm{Si}\right) ; 1.08$ $\left(\mathrm{d},{ }^{2} J_{\mathrm{H}_{\mathrm{A}} \mathrm{H}_{\mathrm{B}}}=11.4 \mathrm{~Hz},{ }^{2} J_{\mathrm{WH}}=6.9 \mathrm{~Hz}, \mathrm{CH}_{\mathrm{A}} H_{B} \mathrm{Si}\right) ; 0.15,0.08\left(\mathrm{SiMe}_{3}\right)$.

$\mathbf{W}\left(\mathrm{CH}_{2} \mathrm{SiMe}_{3}\right)_{3}(=\mathrm{NPh})\left[(\boldsymbol{R})-\mathrm{SC}_{6} \mathrm{H}_{4} \mathrm{CH}(\mathrm{Me}) \mathrm{NMe}_{2}-2\right](6)$. A solution of $\mathrm{Li}\left[(R)-\mathrm{SC}_{6} \mathrm{H}_{4} \mathrm{CH}(\mathrm{Me}) \mathrm{NMe}_{2}-2\right](1.16 \mathrm{~g}, 6.19 \mathrm{mmol})$ in THF $(30 \mathrm{~mL})$ was added dropwise to a stirred solution of 1 ( 3.49 $\mathrm{g}, 6.10 \mathrm{mmol})$ in THF $(20 \mathrm{~mL})$ at $-30^{\circ} \mathrm{C}$. The reaction mixture was stirred for another $3 \mathrm{~h}$ at this temperature, after which the temperature was raised to room temperature. The volatiles were removed in vacuo, leaving a sticky oil which was extracted with hexane $(2 \times 60 \mathrm{~mL})$. The hexane solutions were combined and evacuated to dryness, leaving a brown oil $(3.9 \mathrm{~g}, 90 \%)$. ${ }^{1} \mathrm{H}$ NMR: $\delta 7.88,7.75,7.40,7.13$ (m, m, d, m, 8, Ar H); 6.91 (t, 1, p-H NPh); $4.46\left(\mathrm{q}, 1,{ }^{3} J_{\mathrm{HH}}=6.5 \mathrm{~Hz}, \mathrm{CH}(\mathrm{Me}) \mathrm{N}\right) ; 2.35\left(\mathrm{~s}, 6, \mathrm{NMe}_{2}\right) ; 1.97,1.93$ (dd, sharp AB pattern, ${ }^{2} J_{\mathrm{H}_{\mathrm{A}} \mathrm{H}_{\mathrm{B}}}=9.6 \mathrm{~Hz},{ }^{2} J_{\mathrm{WH}}=8.3 \mathrm{~Hz}, \mathrm{CH}_{2} \mathrm{Si}$ ); $1.51\left(\mathrm{~d}, 3,{ }^{3} J_{\mathrm{HH}}=6.5 \mathrm{~Hz}, \mathrm{CH}(\mathrm{Me}) \mathrm{N}\right) ; 0.13\left(\mathrm{~s}, 27, \mathrm{SiMe}_{3}\right),{ }^{13} \mathrm{C}$ NMR: $\delta 153.7\left(\mathrm{C}_{i p s o} \mathrm{NPh}\right) ; 147.4\left(\mathrm{C}_{i p s o} \mathrm{SAr}\right) ; 142.6,133.5,128.8-$ 127.4, 126.5, 126.3 (Ar C); $73.0\left({ }^{1} J_{\mathrm{WC}}=73.7 \mathrm{~Hz}, \mathrm{CH}_{2} \mathrm{Si}\right) ; 62.7$ $(\mathrm{CH}(\mathrm{Me}) \mathrm{N}) ; 44.3\left(\mathrm{NMe}_{2}\right) ; 22.1(\mathrm{CH}(\mathrm{Me}) \mathrm{N}) ; 2.2\left(\mathrm{SiMe}_{3}\right)$.

$\mathrm{W}\left(\mathrm{CH}_{2} \mathrm{SiMe}_{3}\right)_{3}(=\mathrm{NPh})\left(1-\mathrm{SC}_{10} \mathrm{H}_{6} \mathrm{NMe}_{2}-8\right)(7)$. This reaction was carried out as described for 6 . Complex 7 was obtained quantitatively as a brown oil. ${ }^{1} \mathrm{H}$ NMR: $\delta 7.92(\mathrm{~d}, 1$, naphthyl $\left.\mathrm{H}^{2}\right) ; 7.46-6.89(\mathrm{~m}, 10, \mathrm{Ar} \mathrm{H}) ; 2.84\left(\mathrm{~s}, 6, \mathrm{NMe}_{2}\right) ; 1.79$ (s, 6, ${ }^{2} J_{\mathrm{WH}}$ $\left.=8.5 \mathrm{~Hz}, \mathrm{CH}_{2} \mathrm{Si}\right) ; 0.05\left(\mathrm{~s}, 27, \mathrm{SiMe}_{3}\right) .{ }^{13} \mathrm{C} \mathrm{NMR}: \delta 154.1\left(\mathrm{C}_{i p s o}\right.$ $\mathrm{NPh}) ; 151.8\left(\mathrm{C}_{i p s o} \mathrm{SAr}\right) ; 141.0,137.6,133.9,129.2-127.0,126.6$, $125.7,124.9,123.7,114.0(\mathrm{Ar} \mathrm{C}) ; 71.4\left({ }^{1} J_{\mathrm{WC}}=73.6 \mathrm{~Hz}, \mathrm{CH}_{2} \mathrm{Si}\right)$; $46.2\left(\mathrm{NMe}_{2}\right) ; 2.3\left(\mathrm{SiMe}_{3}\right)$.

$\mathrm{W}\left(\mathrm{CH}_{2} \mathrm{SiMe}_{3}\right)_{3}(=\mathrm{NPh})\left(\mathrm{SC}_{6} \mathrm{H}_{4} \mathrm{NMe}_{2}-2\right)(8)$. This reaction was carried out as described for 6 . Complex 8 was obtained quantitatively as a brown oil. ${ }^{1} \mathrm{H}$ NMR: $\delta 7.75,7.42,7.15-6.85$ (d, d, m, 9, Ar H); 2.79 (s, 6, $\left.\mathrm{NMe}_{2}\right) ; 2.06\left(\mathrm{~s}, 6,{ }^{2} J_{\mathrm{WH}}=8.6 \mathrm{~Hz}\right.$, $\left.\mathrm{CH}_{2} \mathrm{Si}\right) ; 0.15$ (s, 27, $\left.\mathrm{SiMe}_{3}\right) .{ }^{13} \mathrm{C}$ NMR: $\delta 155.2\left(\mathrm{C}_{i p \circ o} \mathrm{SAr}\right) ; 153.9$ $\left(\mathrm{C}_{\text {ipso }} \mathrm{NPh}\right) ; 137.8,136.1,128.6-127.1,125.6,122.9,119.3(\mathrm{Ar} \mathrm{C})$; $72.7\left({ }^{1} J_{\mathrm{wc}}=73.3, \mathrm{CH}_{2} \mathrm{Si}\right) ; 44.5\left(\mathrm{NMe}_{2}\right) ; 2.2\left(\mathrm{SiMe}_{3}\right)$.

W ( $\left.=\mathrm{CHSiMe}_{3}\right)\left(\mathrm{CH}_{2} \mathrm{SiMe}_{3}\right)(=\mathrm{NPh})\left[\mathrm{OCPh}_{2}(2-\mathrm{py})\right]\left(9^{\prime}\right)$. A suspension of $\mathrm{Li} \mathrm{OCPh}_{2}$ (2-py)] $(4.32 \mathrm{~g}, 15.8 \mathrm{mmol})$ in THF (40
$\mathrm{mL})$ was added over $10 \mathrm{~min}$ to a stirred solution of $1(7.87 \mathrm{~g}, 13.8$ mmol) in THF (40 mL). After 3-h reflux the clear, red-brown reaction mixture was evaporated to dryness in vacuo, leaving a brown oil. This residue was extracted with $\mathrm{Et}_{2} \mathrm{O}(2 \times 50 \mathrm{~mL})$. The combined ether fractions were concentrated to $c a .30 \mathrm{~mL}$ and cooled to $-30^{\circ} \mathrm{C}$. The product was obtained as yellow crystals $(8.7 \mathrm{~g}, 89 \%)$. Complex $9^{\prime}$ is obtained as a mixture of two rotamers (with a syn:anti ratio of 10:1). Data for the syn rotamer are as follows. ${ }^{1} \mathrm{H}$ NMR: $\delta 10.67\left(\mathrm{~s}, 1,{ }^{2} J_{\mathrm{WH}}=11.4 \mathrm{~Hz}, \mathrm{H}_{\alpha}\right) ; 8.48(\mathrm{~d}, 1$, py $\left.\mathrm{H}^{6}\right) ; 7.49-6.88$ (m, 16, Ar H); 6.57 (t, 1, p-H NPh); 6.04 (t, 1, py $\mathrm{H}) ; 1.10\left(\mathrm{~d}, 1,{ }^{2} J_{\mathrm{H}_{\mathrm{A}} \mathrm{H}_{\mathrm{B}}}=12.7 \mathrm{~Hz},{ }^{2} J_{\mathrm{WH}}=10.8 \mathrm{~Hz}, \mathrm{CH}_{\mathrm{A}} \mathrm{H}_{\mathrm{B}} \mathrm{Si}\right)$; $0.99\left(\mathrm{~d}, 1,{ }^{2} J_{\mathrm{H}_{\mathrm{B}} \mathrm{H}_{\mathrm{A}}}=12.7 \mathrm{~Hz},{ }^{2} J_{\mathrm{WH}}=10.8 \mathrm{~Hz}, \mathrm{CH}_{\mathrm{A}} \mathrm{H}_{B} \mathrm{Si}\right) ; 0.43,0.32$ $\left(2 \mathrm{~s}, 18, \mathrm{SiMe}_{3}\right) .{ }^{13} \mathrm{C} \mathrm{NMR}: \delta 247.7\left({ }^{1} J_{\mathrm{WC}}=137.2 \mathrm{~Hz},{ }^{1} J_{\mathrm{CH}}=\right.$ $115.1 \mathrm{~Hz}, \mathrm{CHSi}$ ); 168.9 (py C2); 157.1 ( $\mathrm{C}_{\text {ipso }} \mathrm{NPh}$ ); 150.6, 147.6, $146.7,138.4,138.0,128.9-123.0(\mathrm{Ar} C) ; 98.6(\mathrm{OC}) ; 33.3\left({ }^{1} J_{\mathrm{WC}}=\right.$ $\left.103.5 \mathrm{~Hz}, \mathrm{CH}_{2} \mathrm{Si}\right) ; 2.6,2.3\left(2 \mathrm{SiMe}_{3}\right)$. Selected data for the anti rotamer are as follows. ${ }^{1} \mathrm{H}$ NMR: $\delta 11.96\left(\mathrm{~s},{ }^{2} J_{\mathrm{WH}}\right.$ not obsd, $\left.\mathrm{H}_{\alpha}\right)$; $8.30\left(\mathrm{~d}\right.$, py $\left.\mathrm{H}^{6}\right) ; 1.40\left(\mathrm{~d},{ }^{2} J_{\mathrm{H}_{\mathrm{A}} \mathrm{H}_{\mathrm{B}}}=13.0 \mathrm{~Hz},{ }^{2} J_{\mathrm{WH}}\right.$ not obsd, $\mathrm{CH}_{\mathrm{A}} \mathrm{H}_{\mathrm{B}^{-}}$ $\mathrm{Si}) ; 0.92\left(\mathrm{~d},{ }^{2} J_{\mathrm{H}_{\mathrm{B}} \mathrm{H}_{\mathrm{A}}}=12.7 \mathrm{~Hz}, \mathrm{CH}_{\mathrm{A}} H_{B} \mathrm{Si}\right) ; 0.35,0.18\left(2 \mathrm{~s}, \mathrm{SiMe}_{3}\right)$. ${ }^{13} \mathrm{C}$ NMR: $\delta 249.5$ ( ${ }^{1} J_{\mathrm{WC}}$ and $J_{\mathrm{CH}}$ not obsd, CHSi); 167.9 (py C2); $37.4\left({ }^{1} J_{\mathrm{WC}}=104.1 \mathrm{~Hz}, \mathrm{CH}_{2} \mathrm{Si}\right) ; 2.9,2.1\left(2 \mathrm{SiMe}_{3}\right)$. Anal. Calcd for $\mathrm{C}_{32} \mathrm{H}_{40} \mathrm{~N}_{2} \mathrm{OSi}_{2} \mathrm{~W}$ : C, 54.23; $\mathrm{H}, 5.69 ; \mathrm{N}, 3.59$. Found: $\mathrm{C}, 54.25$; $\mathrm{H}, 5.66 ; \mathrm{N}, 4.00$.

$\mathrm{W}\left(\mathrm{CH}_{2} \mathrm{SiMe}_{3}\right)_{3}(=\mathrm{NPh})\left[\mathrm{OCH}\left(\mathrm{CMe}_{3}\right)(2-\mathrm{py})\right](10)$. This reaction was carried out via a procedure similar to the one described for 3. The reaction mixture was kept at room temperature and stirred for $2 \mathrm{~h}$. After removing the volatiles were removed in vacuo, the product was obtained quantitatively as a yellow oil and was pure by NMR. ${ }^{1} \mathrm{H}$ NMR: $\delta 8.46\left(\mathrm{~d}, 1, \mathrm{py} \mathrm{H}^{6}\right) ; 7.56$ (d, 2, o-H NPh); 7.43 (t, 2, m-H NPh); 7.22-6.86 (m, 4, Ar H); 5.76 $\left(\mathrm{s}, 1, \mathrm{CH}\left(\mathrm{CMe}_{3}\right)\right) ; 1.47\left(\mathrm{~s}, 6,{ }^{2} J_{\mathrm{WH}}=9.1 \mathrm{~Hz}, \mathrm{CH}_{2} \mathrm{Si}\right) ; 1.26(\mathrm{~s}, 9$, $\mathrm{CH}\left(\mathrm{CMe}_{3}\right)$ ); 0.14 (s, 27, $\mathrm{SiMe}_{3}$ ). ${ }^{13} \mathrm{C} \mathrm{NMR:} \delta 163.4$ (py C2); 155.2 $\left(\mathrm{C}_{\text {ipso }} \mathrm{NPh}\right) ; 148.5\left(\mathrm{py} \mathrm{C}^{6}\right) ; 134.9,128.4-127.4,125.2,123.3,122.0$ $(\mathrm{ArC}) ; 93.3(\mathrm{OC}) ; 61.1\left({ }^{1} J_{\mathrm{wC}}=78.2 \mathrm{~Hz}, \mathrm{CH}_{2} \mathrm{Si}\right) ; 38.1\left(\mathrm{CH}\left(\mathrm{CMe}_{3}\right)\right)$; $27.5\left(\mathrm{CH}\left(\mathrm{CMe}_{3}\right)\right) ; 2.5\left(\mathrm{SiMe}_{3}\right)$.

$\mathbf{W}\left(=\mathrm{CHSiMe}_{3}\right)\left(\mathrm{CH}_{2} \mathrm{SiMe}_{3}\right)(=\mathrm{NPh})\left[\mathrm{OCH}\left(\mathrm{CMe}_{3}\right)(2-\mathrm{py})\right]$ $\left(10^{\prime}\right)$. A solution of 10 in hexane was heated at reflux for $4 \mathrm{~h}$. The volatiles were removed in vacuo, yielding light brown, solid $10^{\prime}$ almost quantitatively. This complex can be crystallized from pentane at $-30^{\circ} \mathrm{C}$ with considerable loss of product, due to the good solubility of $10^{\prime}$ in this solvent. Complex $10^{\prime}$ is obtained as a mixture of two rotamers (with a syn:anti ratio of 6:4). Selected data for the syn rotamer are as follows. ${ }^{1} \mathrm{H}$ NMR: $\delta 10.75(\mathrm{~s}, 1$, $\left.{ }^{2} J_{\mathrm{WH}}=11.1 \mathrm{~Hz}, \mathrm{H}_{\alpha}\right) ; 8.46\left(\mathrm{~d}, 1, \mathrm{py} \mathrm{H} \mathrm{H}^{6}\right) ; 7.2-6.6(\mathrm{~m}, 7, \mathrm{Ar} \mathrm{H}) ; 6.22$ (d, 1, py H); 5.48 (s, 1, CH(CMes)); 0.80 (s, 9, CH(CMes)); 0.43, $0.42\left(2 \mathrm{~s}, 18, \mathrm{SiMe}_{3}\right) .{ }^{13} \mathrm{C}$ NMR: $\delta 244.7\left(1 J_{\mathrm{WC}}=138.9 \mathrm{~Hz},{ }^{1} J_{\mathrm{CH}}\right.$ $=115.6 \mathrm{~Hz}, \mathrm{CHSi}) ; 166.2\left(\mathrm{py} \mathrm{C}^{2}\right) ; 157.5\left(\mathrm{C}_{i p s o} \mathrm{NPh}\right) ; 97.2(\mathrm{OC})$; $37.6\left(\mathrm{CH}\left(\mathrm{CMe}_{3}\right)\right) ; 31.9\left({ }^{1} J_{\mathrm{WC}}=105.4 \mathrm{~Hz}, \mathrm{CH}_{2} \mathrm{Si}\right) ; 2.5\left(2 \mathrm{SiMe}_{3}\right)$. Selected data for the anti rotamer are as follows. 'H NMR: $\delta$ $11.63\left(\mathrm{~s}, 1,{ }^{2} J_{\mathrm{WH}}\right.$ not obsd, $\left.\mathrm{H}_{\alpha}\right) ; 8.27\left(\mathrm{~d}, 1, \mathrm{py} \mathrm{H} \mathrm{H}^{6}\right) ; 7.2-6.6(\mathrm{~m}, 7$, $\mathrm{Ar} \mathrm{H}) ; 6.13$ (d, 1, py H); 5.50 (s, 1, CH(CMe $\left.{ }_{3}\right)$ ); 0.80 (s, 9, CH$\left.\left(\mathrm{CMe}_{3}\right)\right) ; 0.37,0.19\left(2 \mathrm{~s}, 18, \mathrm{SiMe}_{3}\right) .{ }^{13} \mathrm{C} \mathrm{NMR}: \delta 245.7\left({ }^{1} J_{\mathrm{WC}}=\right.$ $\left.\left.146.2 \mathrm{~Hz},{ }^{1} J_{\mathrm{CH}}=134.9 \mathrm{~Hz}, \mathrm{CHSi}\right) ; 165.9(\mathrm{py} \mathrm{C})^{2}\right) ; 157.5\left(\mathrm{C}_{i p s o}\right.$ $\mathrm{NPh}) ; 96.7(\mathrm{OC}) ; 37.3\left(\mathrm{CH}\left(\mathrm{CMe}_{3}\right)\right) ; 35.1\left({ }^{1} J_{\mathrm{WC}}=104.1 \mathrm{~Hz}, \mathrm{CH}_{2^{-}}\right.$ $\mathrm{Si}) ; 2.9,1.9\left(2 \mathrm{SiMe}_{3}\right)$. Anal. Calcd for $\mathrm{C}_{24} \mathrm{H}_{40} \mathrm{~N}_{2} \mathrm{OSi}_{2} \mathrm{~W}: \mathrm{C}, 47.05$; $\mathrm{H}, 6.58 ; \mathrm{N}, 4.57$. Found $\mathrm{C}, 46.41 ; \mathrm{H}, 6.60 ; \mathrm{N}, 4.54$.

$\mathrm{W}\left(\mathrm{CH}_{2} \mathrm{SiMe}_{3}\right)_{2}(=\mathrm{NPh})\left(\mathrm{OCMe}_{3}\right)\left[\mathrm{OCMe}_{2}(2-\mathrm{py})\right]$ (11). Li[OCMe 2 (2-py)] $(1.66 \mathrm{~g}, 12.1 \mathrm{mmol})$ was added as a solid to a stirred solution of $2(6.41 \mathrm{~g}, 11.5 \mathrm{mmol})$ in $\mathrm{Et}_{2} \mathrm{O}(60 \mathrm{~mL})$, and the mixture was stirred for $4 \mathrm{~h}$. The volatiles were removed in vacuo, leaving an orange solid. This solid was extracted with hexane $(2 \times 50 \mathrm{~mL})$, and the combined hexane fractions were cooled to $-30^{\circ} \mathrm{C}$, affording the product as orange crystals in $85 \%$ yield. ${ }^{1} \mathrm{H}$ NMR: $\delta 8.83\left(\mathrm{~d}, 1, \mathrm{py} \mathrm{H} \mathrm{H}^{6}\right) ; 7.68(\mathrm{~d}, 2, o-\mathrm{H} \mathrm{NPh}) ; 7.22(\mathrm{t}, 2$, $m$-H NPh); 6.93, 6.87, 6.61, 6.47 (t, t, m, d, 4, Ar H); 1.56 (s, 9, $\left.\mathrm{OCMe}_{3}\right) ; 1.52\left(\mathrm{~s}, 6, \mathrm{CMe}_{2}\right) ; 0.24\left(\mathrm{~s}, 18, \mathrm{SiMe}_{\mathrm{s}}\right) ; 0.19\left(\mathrm{~d}, 2,{ }^{2} J_{\mathrm{H}_{\mathrm{A}} \mathrm{H}_{\mathrm{B}}}\right.$ $\left.=13.4 \mathrm{~Hz},{ }^{2} J_{\mathrm{WH}}=6.8 \mathrm{~Hz}, \mathrm{CH}_{A} \mathrm{H}_{\mathrm{B}} \mathrm{Si}\right) ;-0.20\left(\mathrm{~d}, 2,{ }^{2} J_{\mathrm{H}_{A} \mathrm{H}_{\mathrm{B}}}=13.4\right.$ $\left.\mathrm{Hz},{ }^{2} J_{\mathrm{WH}}=6.8 \mathrm{~Hz}, \mathrm{CH}_{\mathrm{A}} H_{B} \mathrm{Si}\right) .{ }^{13} \mathrm{C}$ NMR: $\delta 167.4\left(\mathrm{py} \mathrm{C}^{2}\right) ; 155.7$ $\left(\mathrm{C}_{i p s o} \mathrm{NPh}\right) ; 145.2$ (py C6); 137.5, 128.8-127.7, 125.8 (Ar C); 87.3, $82.5\left(\mathrm{OC}\right.$ and $\left.\mathrm{OCMe}_{3}\right) ; 36.1\left({ }^{1} \mathrm{~J}_{\mathrm{WC}}=67.2 \mathrm{~Hz}, \mathrm{CH}_{2} \mathrm{Si}\right) ; 31.5(\mathrm{OCMe})$; 31.2 $\left(\mathrm{CMe}_{2}\right) ; 3.8\left(\mathrm{SiMe}_{3}\right)$. Anal. Calcd for $\mathrm{C}_{26} \mathrm{H}_{46} \mathrm{~N}_{2} \mathrm{O}_{2} \mathrm{Si}_{2} \mathrm{~W}: \mathrm{C}$, $47.41 ; \mathrm{H}, 7.07 ; \mathrm{N}, 4.25$. Found: $\mathrm{C}, 47.93 ; \mathrm{H}, 7.20 ; \mathrm{N}, 4.34$. 
Table 8. Crystal Data and Details of the Structure Determination of Complexes 9 and 9

formula
mol wt
cryst syst
space group
$a, b, c(\AA)$
$\alpha, \beta, \gamma(\mathrm{deg})$
$V\left(\AA^{3}\right)$
$Z$
$D_{\text {calc }}\left(\mathrm{g} \mathrm{cm}^{-3}\right)$
$F(000)$
$\mu\left(\mathrm{cm}^{-1}\right)$
cryst size (mm)
temp $(\mathrm{K})$
$\theta_{\min }, \theta_{\max }($ deg)
radiation $(\AA)$
$\Delta \omega($ deg)
Horiz and vert aperture $(\mathrm{mm})$
linear decay (\%)
ref rflns
total, unique no. of data
no. of obsd data $(I>2.5 \sigma(I))$

no. of refined params
no. of rflns
weighting scheme
final $R, R_{\mathrm{w}}, S$
max, av shift/error
min, max resd dens $\left.9 \mathrm{e} / \AA^{3}\right)$

$\mathrm{W}\left(\mathrm{CH}_{2} \mathrm{CMe}_{3}\right)_{2}(=\mathrm{NPh})\left(\mathrm{OCMe}_{3}\right)\left[\mathrm{OCMe}_{2}(2-\mathrm{py})\right](11 \mathrm{a})$. This complex is prepared as described for 11 . W $\left(\mathrm{CH}_{2} \mathrm{CMe}_{3}\right)_{2} \mathrm{Cl}$ $(=\mathrm{NPh})\left(\mathrm{OCMe}_{3}\right)^{25}(4.56 \mathrm{~g}, 8.7 \mathrm{mmol})$ and a slight excess of $\mathrm{Li}-$ [OCMe $\left(2\right.$-py)] give $11 \mathrm{a}$ as yellow crystals in $89 \%$ yield. ${ }^{1} \mathrm{H}$ NMR: $\delta 8.54$ (d, 1, py H6); 7.75 (d, 2, o-H NPh); 7.20 (t, $2, m-\mathrm{H}$ $\mathrm{NPh}) ; 6.86,6.56,6.47$ (m, m, d, 4, Ar H); 1.64 (s, 6, $\left.\mathrm{CMe}_{2}\right) ; 1.60$ $\left(\mathrm{s}, 9, \mathrm{OCMe}_{3}\right) ; 1.48\left(\mathrm{~d}, 2,{ }^{2} J_{\mathrm{H}_{\mathrm{A}} \mathrm{H}_{\mathrm{B}}}=13.1 \mathrm{~Hz},{ }^{2} J_{\mathrm{WH}}=8.7 \mathrm{~Hz}\right.$, $\left.\mathrm{CH}_{\mathrm{A}} \mathrm{H}_{\mathrm{B}} \mathrm{C}\right) ; 1.36\left(\mathrm{~s}, 18, \mathrm{CMe}_{3}\right) ; 1.10\left(\mathrm{~d}, 2,{ }^{2} J_{\mathrm{H}_{\mathrm{A}} \mathrm{H}_{\mathrm{B}}}=13.1 \mathrm{~Hz},{ }^{2} J_{\mathrm{WH}}\right.$ $\left.=8.7 \mathrm{~Hz}, \mathrm{CH}_{\mathrm{A}} H_{B} \mathrm{C}\right) .{ }^{13} \mathrm{C} \mathrm{NMR:} \delta 168.1\left(\mathrm{py} \mathrm{C}^{2}\right) ; 156.2\left(\mathrm{C}_{i p s 0} \mathrm{NPh}\right) ;$ 145.1 (py C6); 137.6, 128.6-127.6, 125.4, 123.1, 121.5 (Ar C); 86.9, $82.6(\mathrm{OC}$ and $\mathrm{OCMe}) ; 71.8\left({ }^{1} J_{\mathrm{WC}}=73.0 \mathrm{~Hz}, \mathrm{CH}_{2} \mathrm{CMe}_{3}\right) ; 37.4$ $\left(\mathrm{CH}_{2} \mathrm{CMe}_{3}\right) ; 35.4\left(\mathrm{CH}_{2} \mathrm{CMe} e_{3}\right) ; 31.7\left(\mathrm{CMe}_{2}\right) ; 31.5\left(\mathrm{OCMe}_{3}\right)$. Anal. Calcd for $\mathrm{C}_{28} \mathrm{H}_{46} \mathrm{~N}_{2} \mathrm{O}_{2} \mathrm{~W}$ : C, 53.68; $\mathrm{H}, 7.40 ; \mathrm{N}, 4.47$. Found: $\mathrm{C}$ $54.74 ; \mathrm{H}, 7.49 ; \mathrm{N}, 4.40$.

$\mathrm{W}\left(\mathrm{CH}_{2} \mathrm{SiMe}_{3}\right)_{2}(=\mathrm{NPh})\left(\mathrm{OCMe}_{3}\right)[\mathrm{OCMe}(\mathrm{Ph})(2-\mathrm{py})]$ (12). This complex is prepared as described for 11. Li[OCMe $(\mathrm{Ph})$. (2-py)] (1.29 g, $6.3 \mathrm{mmol})$ and an equimolar amount of 2 yield 12 as a red crystalline solid (78\%). ${ }^{1} \mathrm{H}$ NMR: $\delta 8.73\left(\mathrm{~d}, 1, \mathrm{py} \mathrm{H}^{6}\right)$; 7.68, $7.40(2 \mathrm{~d}, 4,0-\mathrm{H} \mathrm{NPh}$ and $\mathrm{Ph}) ; 7.26-6.66(\mathrm{~m}, 9, \mathrm{Ar} \mathrm{H}) ; 1.87$ (s, 3, CMe), 1.56 (s, 9, OCMe $\left.{ }_{3}\right), 0.32$ and $-0.05\left(2 \mathrm{~s}, 18, \mathrm{SiMe}_{3}\right)$; $0.22\left(\mathrm{~d}, 2,{ }^{2} J_{\mathrm{H}_{\mathrm{H}}}=13.2 \mathrm{~Hz},{ }^{2} J_{\mathrm{WH}}=8.9 \mathrm{~Hz}, \mathrm{CH}_{\mathrm{A}} \mathrm{H}_{\mathrm{B}} \mathrm{Si}\right) ; 0.06(\mathrm{~d}$, $\left.2,{ }^{2} J_{\mathrm{H}_{\mathrm{A}} \mathrm{H}_{\mathrm{B}}}=13.2 \mathrm{~Hz},{ }^{2} J_{\mathrm{WH}}=8.9 \mathrm{~Hz}, \mathrm{CH}_{\mathrm{A}} \mathrm{H}_{\mathrm{B}} \mathrm{Si}\right) ;-0.26(2 \mathrm{dd}, 4$, $\left.{ }^{2} J_{\mathrm{H}_{\mathrm{A}} \mathrm{H}_{\mathrm{B}}}=13.2 \mathrm{~Hz},{ }^{2} J_{\mathrm{WH}}=8.9 \mathrm{~Hz}, \mathrm{CH}_{\mathrm{A}} H_{B} \mathrm{Si}\right) .{ }^{13} \mathrm{C}$ NMR: $\delta 164.5$ $\left(\right.$ py C $\left.{ }^{2}\right) ; 155.8\left(\mathrm{C}_{i p s o} \mathrm{NPh},{ }^{2} J_{\mathrm{wC}}=38.9 \mathrm{~Hz}\right) ; 146.2\left(\mathrm{C}_{i p s o} \mathrm{Ph}\right) ; 145.7$ (py C $\left.{ }^{6}\right) ; 136.7,132.2,128.7-127.6,127.0,125.8,124.1,123.6$ (Ar C); $91.2(\mathrm{OC}) ; 82.9\left(\mathrm{OCMe}_{3}\right), 36.8\left({ }^{1} \mathrm{~J}_{\mathrm{WC}}=66.2 \mathrm{~Hz}, \mathrm{CH}_{2} \mathrm{Si}\right), 36.2$ $\left({ }^{1} J_{\mathrm{wC}}=67.5 \mathrm{~Hz}, \mathrm{CH}_{2} \mathrm{Si}\right), 32.6(\mathrm{CMe}), 31.3\left(\mathrm{OCMe}_{3}\right), 3.8,3.4$ ( $\mathrm{SiMe}_{3}$ ). Anal. Calcd for $\mathrm{C}_{31} \mathrm{H}_{48} \mathrm{~N}_{2} \mathrm{O}_{2} \mathrm{Si}_{2} \mathrm{~W}: \mathrm{C}, 51.66 ; \mathrm{H}, 6.71 ; \mathrm{N}$, 3.89. Found: C, $51.75 ; \mathrm{H}, 6.79 ; \mathrm{N}, 4.04$.

$\mathrm{W}\left(\mathrm{CH}_{2} \mathrm{SiMe}_{3}\right)_{2}(=\mathrm{NPh})\left(\mathrm{OCMe}_{3}\right)\left[\mathrm{OCH}\left(\mathrm{CMe}_{3}\right)(2-\mathrm{py})\right]$ (13). This complex is prepared as described for $11 . \mathrm{Li}\left[\mathrm{OCH}\left(\mathrm{CMe}_{3}\right)\right.$. (2-py)] $(0.79 \mathrm{~g}, 4.6 \mathrm{mmol})$ and an equimolar amount of 2 yield 13 as an orange solid $(92 \%)$. ${ }^{1} \mathrm{H}$ NMR: $\delta 8.74\left(\mathrm{~d}, 1\right.$, py $\left.\mathrm{H}^{6}\right) ; 7.66$ (d, 2, o-H NPh); 7.26 (t, 2, m-H NPh); 7.04-6.63 (m, 4, Ar H); 5.22 (s, 1, $\left.\mathrm{CHCMe}_{3}\right) ; 1.55\left(\mathrm{~s}, 9, \mathrm{OCMe}_{3}\right) ; 1.17\left(\mathrm{~s}, 9, \mathrm{CHCMe}_{3}\right) ; 0.30$ $0.27\left(2 \mathrm{~s}, 18, \mathrm{SiMe}_{3}\right) ; 0.47\left(\mathrm{~d}, 1,{ }^{2} J_{\mathrm{H}_{\mathrm{H}}}=13.2 \mathrm{~Hz},{ }^{2} J_{\mathrm{WH}}=9.0 \mathrm{~Hz}\right.$, $\left.\mathrm{CH}_{\mathrm{A}} \mathrm{H}_{\mathrm{B}} \mathrm{Si}\right) ; 0.10\left(\mathrm{~d}, 1,{ }^{2} J_{\mathrm{H}_{\mathrm{A}} \mathrm{H}_{\mathrm{B}}}=13.2 \mathrm{~Hz},{ }^{2} J_{\mathrm{WH}}=9.0 \mathrm{~Hz}, \mathrm{CH}_{A} \mathrm{H}_{\mathrm{B}}-\right.$ $\mathrm{Si}) ; 0.17\left(\mathrm{~d}, 1,{ }^{2} J_{\mathrm{H}_{\mathrm{A}} \mathrm{H}_{\mathrm{B}}}=13.2 \mathrm{~Hz},{ }^{2} J_{\mathrm{WH}}=9.0 \mathrm{~Hz}, \mathrm{CH}_{\mathrm{A}} H_{B} \mathrm{Si}\right) ;-0.43$ (d, $\left.1,{ }^{2} J_{\mathrm{H}_{\mathrm{A}} \mathrm{H}_{\mathrm{B}}}=13.2 \mathrm{~Hz},{ }^{2} J_{\mathrm{WH}}=9.0 \mathrm{~Hz}, \mathrm{CH}_{\mathrm{A}} H_{B} \mathrm{Si}\right) .{ }^{13} \mathrm{C} \mathrm{NMR}$ : $\delta 162.5$ (py C $\left.{ }^{2}\right) ; 155.7\left(\mathrm{C}_{i p s o} \mathrm{NPh}\right) ; 146.5$ (py C6); 136.7, 129.1, 128.3-127.7, 125.9, 123.2, 122.3 ( $\mathrm{Ar} \mathrm{C}) ; 94.8(\mathrm{OC}) ; 82.7\left(\mathrm{OCMe}_{3}\right)$;

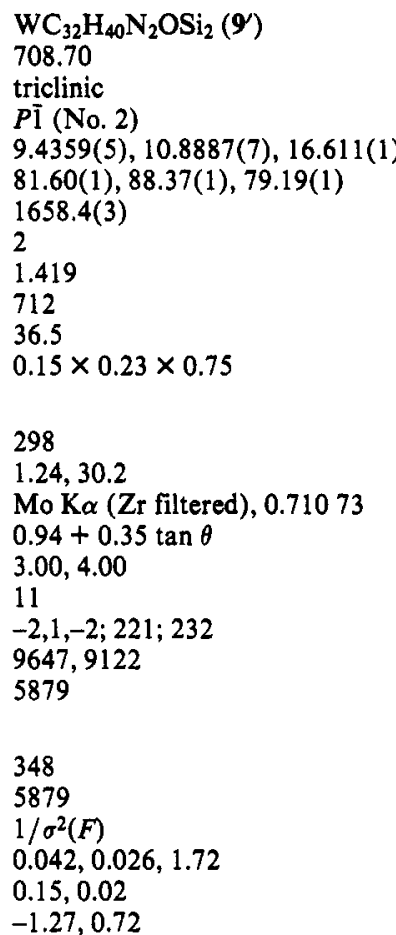

$38.8\left({ }^{1} J_{\mathrm{WC}}=70.4 \mathrm{~Hz}, \mathrm{CH}_{2} \mathrm{Si}\right) ; 38.6\left(\mathrm{CH}\left(\mathrm{CMe}_{3}\right)\right) ; 33.4\left({ }^{1} J_{\mathrm{WC}}=64.9\right.$ $\left.\mathrm{Hz}, \mathrm{CH}_{2} \mathrm{Si}\right) ; 31.3\left(\mathrm{OCMe}_{3}\right) ; 28.2\left(\mathrm{CH}\left(\mathrm{CMe}_{3}\right)\right) ; 3.9,3.4\left(\mathrm{SiMe}_{3}\right)$. Anal. Calcd for $\mathrm{C}_{28} \mathrm{H}_{50} \mathrm{~N}_{2} \mathrm{O}_{2} \mathrm{Si}_{2} \mathrm{~W}: \mathrm{C}, 48.97 ; \mathrm{H}, 7.34 ; \mathrm{N}, 4.08$. Found: C, 48.79; H, 6.99; N, 4.16.

$\mathrm{W}\left(\mathrm{CH}_{2} \mathrm{SiMe}_{3}\right)_{2}(=\mathrm{NPh})\left(\mathrm{OCMe}_{3}\right)\left[\mathrm{OCMe}\left(\mathrm{CMe}_{3}\right)(2-\mathrm{py})\right]$ (14). This complex is prepared as described for 11. $\mathrm{Li}\left[\mathrm{OCMe}\left(\mathrm{CMe}_{3}\right)-\right.$ (2-py)] $(0.58 \mathrm{~g}, 3.1 \mathrm{mmol})$ and an equimolar amount of 2 yield 14 as an orange solid $(68 \%)$. ${ }^{1} \mathrm{H}$ NMR: $\delta 8.73\left(\mathrm{~d}, 1, \mathrm{py} \mathrm{H} \mathrm{H}^{6}\right) ; 7.66$ (d, 2, o-H NPh); 7.24 (t, 2, m-H NPh); 6.93 (m, 2, Ar H); 6.86 (t, $1, p-\mathrm{H} \mathrm{NPh}$ ); 6.65 (m, 1, py H); 1.60 (s, 3, $\mathrm{CMe}\left(\mathrm{CMe}_{3}\right)$ ); 1.59 (s, 9, $\left.\mathrm{OCMe}_{3}\right) ; 1.10\left(\mathrm{~s}, 9, \mathrm{CMe}\left(\mathrm{CMe}_{3}\right)\right) ; 0.30,0.25\left(2 \mathrm{~s}, 18, \mathrm{SiMe}_{3}\right)$; $0.29\left(\mathrm{~d}, 1,{ }^{2} J_{\mathrm{H}_{A} \mathrm{H}_{\mathrm{B}}}=11.5 \mathrm{~Hz},{ }^{2} J_{\mathrm{WH}}\right.$ not obsd, $\left.\mathrm{CH}_{\mathrm{A}} \mathrm{H}_{\mathrm{B}} \mathrm{Si}\right) ; 0.22(\mathrm{~d}$, $1,{ }^{2} J_{\mathrm{H}_{\mathrm{A}} \mathrm{H}_{\mathrm{B}}}=11.5 \mathrm{~Hz},{ }^{2} J_{\mathrm{WH}}$ not obsd, $\left.\mathrm{CH}_{\mathrm{A}} H_{\mathrm{B}} \mathrm{Si}\right) ; 0.16\left(\mathrm{~d}, 1,{ }^{2} J_{\mathrm{H}_{\mathrm{A}} \mathrm{H}_{\mathrm{B}}}\right.$ $\left.=13.8 \mathrm{~Hz},{ }^{2} J_{\mathrm{WH}}=7.7 \mathrm{~Hz}, \mathrm{CH}_{A} \mathrm{H}_{\mathrm{B}} \mathrm{Si}\right) ;-0.31\left(\mathrm{~d}, 1,{ }^{2} J_{\mathrm{H}_{A} \mathrm{H}_{\mathrm{B}}}=13.8\right.$ $\left.\mathrm{Hz},{ }^{2} J_{\mathrm{WH}}=7.7 \mathrm{~Hz}, \mathrm{CH}_{\mathrm{A}} H_{B} \mathrm{Si}\right) .{ }^{13} \mathrm{C}$ NMR: $\delta 166.6\left(\mathrm{py} \mathrm{C}^{2}\right) ; 155.7$ $\left(\mathrm{C}_{i p s o} \mathrm{NPh}\right) ; 146.3\left(\mathrm{py} \mathrm{C}^{6}\right) ; 136.9,129.1,128.3-127.7,126.0,123.4$, 122.4 (Ar C); 95.8 (OC); $82.5\left(\mathrm{OCMe}_{3}\right) ; 42.5\left(\mathrm{CMe} \mathrm{CMe}_{3}\right)$ ); 37.7 $\left({ }^{1} J_{\mathrm{WC}}=69.7 \mathrm{~Hz}, \mathrm{CH}_{2} \mathrm{Si}\right) ; 36.3\left({ }^{1} J_{\mathrm{WC}}=64.6 \mathrm{~Hz}, \mathrm{CH}_{2} \mathrm{Si}\right) ; 31.2$ $\left(\mathrm{OCMe}_{3}\right) ; 27.9\left(\mathrm{CH}\left(\mathrm{CMe}_{3}\right)\right) ; 4.12,4.10\left(\mathrm{SiMe}_{3}\right)$.

$\mathrm{W}\left(\mathrm{CH}_{2} \mathrm{SiMe}_{3}\right)_{2}(=\mathrm{NPh})\left(\mathrm{OC}_{6} \mathrm{H}_{3} \mathrm{Me}_{2}-3,5\right)\left[\mathrm{OCMe}_{2}(2-\mathrm{py})\right]$ (15). This complex is prepared as described for 11 . $\mathrm{Li}\left[\mathrm{OCMe}_{2}(2-\mathrm{py})\right]$ $(0.79 \mathrm{~g}, 4.6 \mathrm{mmol})$ and an equimolar amount of $\mathrm{W}\left(\mathrm{CH}_{2} \mathrm{SiMe}_{3}\right)_{2-}$ $\mathrm{Cl}(=\mathrm{NPh})\left(\mathrm{OC}_{6} \mathrm{H}_{3} \mathrm{Me}_{2}-3,5\right)$ yield 15 as red crystals $(81 \%) .{ }^{1} \mathrm{H}$ NMR: $\delta 8.98\left(\mathrm{~d}, 1, \mathrm{py} \mathrm{H}^{6}\right) ; 7.67(\mathrm{~d}, 2, o-\mathrm{H} \mathrm{NPh}) ; 7.19(\mathrm{t}, 2, m-\mathrm{H}$ $\mathrm{NPh}$ ); 7.12-6.36 ( $\mathrm{Ar} \mathrm{H}) ; 2.33$ (s, 6, $\left.\mathrm{Me}_{2}-3,5\right) ; 1.43$ (s, 6, $\left.\mathrm{CMe}_{2}\right) ; 0.44$ (br, 4, $\mathrm{CH}_{2} \mathrm{Si}$ ); 0.29 (s, 18, $\mathrm{SiMe}_{3}$ ). ${ }^{13} \mathrm{C}$ NMR: $\delta 166.2,163.8$ (py $\mathrm{C}^{2}$ and $\left.\mathrm{C}_{i p s o} \mathrm{OAr}\right) ; 155.0\left(\mathrm{C}_{i p s o} \mathrm{NPh}\right) ; 145.8\left(\right.$ py C $\left.^{6}\right) ; 138.7,138.0$, 128.9-127.7, 126.4, 123.9, 123.2, 120.8, 118.7, 117.7 (Ar C); 90.2 (OC); 44.2 (br, $\mathrm{CH}_{2} \mathrm{Si},{ }^{1} J_{\mathrm{wc}}$ not obsd); $29.5\left(\mathrm{CMe}_{2}\right) ; 21.6\left(\mathrm{Me}_{2-}\right.$ 3,5); 3.5 ( $\left.\mathrm{SiMe}_{3}\right)$. Anal. Calcd for $\mathrm{C}_{30} \mathrm{H}_{46} \mathrm{~N}_{2} \mathrm{O}_{2} \mathrm{Si}_{2} \mathrm{~W}$ : C, 50.98; $\mathrm{H}$, $6.56 ; \mathrm{N}, 3.96$. Found: C, 50.92; H, 6.63; N, 3.89 .

Metal Complex Catalyzed ROMP Reactions with Norbornene. In a typical experiment a solution of norbornene in benzene $(10 \mathrm{~mL}$ of a $1.25 \mathrm{M}$ solution; $12.5 \mathrm{mmol}$ ) was added to a stirred solution of the catalyst in benzene $(1 \mathrm{~mL}$ of a $0.05 \mathrm{M}$ solution; $50 \mu \mathrm{mol}$ ) under nitrogen. After $30 \mathrm{~min}$ this reaction mixture was quenched with a drop of benzaldehyde and poured into $100 \mathrm{~mL}$ of ethanol. The precipitated polymer was collected by filtration, washed with ethanol, and dried in vacuo. Yields were nearly quantitative. With complexes $9^{\prime}$ and $10^{\prime}$ the reaction vessel was heated at ca. $70^{\circ} \mathrm{C}$ in an oil bath to complete the polymerization reaction within $30 \mathrm{~min}$. 
X-ray Structure Determination and Refinement of Complexes 9 and $9^{\prime} . \mathrm{C}_{38} \mathrm{H}_{62} \mathrm{~N}_{2} \mathrm{OSi}_{3} \mathrm{~W}(9)$. A yellow crystal mounted in a Lindemann capillary was measured on an Enraf-Nonius CAD-4 diffractometer using $\mathrm{Zr}$-filtered Mo $\mathrm{K} \alpha$ radiation $(\lambda=$ $0.71073 \AA$ ). Unit cell parameters were derived from the SET4 setting angles of 25 reflections in the range $6<\theta<11^{\circ}$. Reflection profiles were broad. Pertinent data are given in Table 8. Data were corrected for Lorentz-polarization effects, a linear decay of $11 \%$, and absorption/extinction (DIFABS; ${ }^{31}$ correction range $0.68-1.18$ ). The structure was solved with DIRDIF92 $2^{32}$ and refined on $F$ by full-matrix least squares (SHELX76). ${ }^{33}$ Final $R=0.063$ and $R_{\mathrm{w}}=0.053\left(w^{-1}=\sigma^{2}(F)+0.000256 F^{2}\right)$ for 2644 reflections with $I \geq 2.5 \sigma(I)$ and 415 parameters. Hydrogen atoms were included at calculated positions. One of the $\mathrm{Si}\left(\mathrm{CH}_{3}\right)_{3}$ groups was refined with a disorder model. A final difference map showed no density outside -1.28 and +1.26 e $\AA^{-3}$ (near W). Geometric calculations and illustrations were performed with PLATON ${ }^{34}$ on a DECstation 5000 .

$\mathrm{C}_{32} \mathrm{H}_{40} \mathrm{~N}_{2} \mathrm{OSi} \mathrm{Si}_{2}\left(9^{\prime}\right)$. An orange, rod-shaped crystal mounted in a Lindemann glass capillary was measured on an Enraf-Nonius CAD-4 diffractometer using $\mathrm{Zr}$-filtered Mo $\mathrm{K} \alpha$ radiation $(\lambda=$ $0.71073 \AA$ ). Unit cell parameters were derived from the SET4 setting angles of 25 reflections in the range $10<\theta<16^{\circ}$. Pertinent

(31) Walker, N.; Stuart, D. Acta Crystallogr. 1983, A39, 158.

(32) Beurskens, P. T.; Admiraal, G.; Beurskens, G.; Bosman, W. P.; Garcia-Granda, S.; Gould, R. O. The DIRDIF Program System, Technical Report of the Crystallographic Laboratory; University of Nijmegen Nijmegen, The Netherlands, 1992.

(33) Sheldrick, G. M. SHELX76: Crystal Structure Analysis Package; University of Cambridge: Cambridge, England, 1976.

(34) Spek, A. L. Acta Crystallogr. 1990, A46, C34. data are given in Table 8. Data were corrected for Lorentzpolarization effects, a linear decay of $11 \%$, and absorption/ extinction (DIFABS; 31 correction range $0.80-1.18$ ). The structure was solved with SHELXS86/PATT ${ }^{35}$ and refined on $F$ with SHELX76. ${ }^{33}$ Final $R=0.042$ and $R_{w}=0.026$ for 5879 reflections with $I \geq 2.5 \sigma(I)$ and 348 parameters. All hydrogen atoms were taken into account at calculated positions, except for the hydrogen atom on $C(23)$, which was located from a difference map and refined; weights based on counting statistics were used. A final difference Fourier showed no residual density outside -1.27 and +0.72 e $\AA^{-3}$ (near W). Geometric calculations and illustrations were performed with PLATON ${ }^{34}$ on a DECstation 5000.

Acknowledgment. This work was supported in part (P.A.v.d.S., W.J.J.S., and A.L.S.) by the Netherlands Foundation for Chemical Research (SON) with financial aid from the Netherlands Organisation for Advancement of Pure Research (NWO).

Supplementary Material Available: Figures showing the ${ }^{1} \mathrm{H}$ and ${ }^{13} \mathrm{C}$ NMR spectra of complexes $3,6,7$, and 8 and tables of anisotropic thermal parameters, all $\mathrm{H}$ atom parameters, bond lengths, and bond angles for 9 and $9^{\prime}$ (28 pages). Ordering information is given on any current masthead page.

\section{OM9305430}

(35) Sheldrick, G. M. SHELXS86: Program for Crystal Structure Determination; University of Göttingen: Göttingen, Federal Republic of Germany, 1986. 